\title{
Evidence for Plio-Pleistocene north-south extension at the southern margin of the Tibetan Plateau, Nyalam region
}

\author{
Jeni A. McDermott, ${ }^{1,2}$ Kelin X. Whipple, ${ }^{1}$ Kip V. Hodges, ${ }^{1}$ and Matthijs C. van Soest ${ }^{1}$ \\ Received 14 July 2012; revised 17 December 2012; accepted 31 January 2013.
}

[1] The southern Tibetan Plateau margin between $\sim 83^{\circ} \mathrm{E}$ and $86.5^{\circ} \mathrm{E}$ is defined by an abrupt change from the low-relief Tibetan Plateau to the rugged topography and deep gorges of the Himalaya. This physiographic transition lies well to the north of active thrusting, and thus, the mechanism responsible for the distinct topographic break remains the focus of much debate. While numerous studies have utilized thermochronology to examine the exhumation history of the Himalaya, few have done so with respect to variations across the Himalaya-Tibetan Plateau transition. In this work, we examine the nature of the transition where it is accessible and well-defined in the Nyalam valley of south-central Tibet. We employ several new and previously published thermochronologic datasets (with a closure temperature range of $\sim 70^{\circ} \mathrm{C}-300^{\circ} \mathrm{C}$ ) in conjunction with river incision patterns inferred by the longitudinal profile of the Bhote Kosi River. The results reveal a sharp change in cooling rate at $\sim 3.5 \mathrm{Ma}$ at a location corresponding to a pronounced river knickpoint representing a sharp increase in river gradient and presumably incision rate (a proxy for rock uplift). Margin retreat models for the physiographic transition are inconsistent with the cooling pattern revealed by low-temperature thermochronologic data. Models invoking passive uplift of the upper crust over a midcrustal ramp and associated duplex to account for the physiographic transition do not explain the observed break in cooling rate there, although they may explain a suggesting in the thermochronologic data of progressively increasing exhumation rates south of the transition. The simplest model consistent with all observations is that passive uplift is augmented by contemporaneous differential uplift across a young (Pliocene-Quaternary) normal fault at the physiographic transition. Drawing on observations elsewhere, we hypothesize that similar structural relationships may be characteristic of the Tibetan Plateau-Himalaya transition from $\sim 83^{\circ} \mathrm{E}-86.5^{\circ} \mathrm{E}$.

Citation: McDermott, J. A., K. X. Whipple, K. V. Hodges, and M. C. van Soest (2013), Evidence for Plio-Pleistocene northsouth extension at the southern margin of the Tibetan Plateau, Nyalam region, Tectonics, 32, doi:10.1002/tect.20018.

\section{Introduction}

[2] The Himalayan mountain chain is arguably the most dramatic landscape on Earth, marked by nine of the ten highest peaks in the world, yet active deformation within the Himalayan realm is widely believed to be restricted to thrusting at the range front, $\sim 150 \mathrm{~km}$ south of the high peaks [e.g., DeCelles et al., 1998a; Cattin and Avouac, 2000; Lavé and Avouac, 2000; DeCelles et al., 2001; Bollinger et al., 2006]. Between $\sim 83^{\circ} \mathrm{E}$ and $86.5^{\circ} \mathrm{E}$, the high peaks roughly

\footnotetext{
${ }^{1}$ School of Earth and Space Exploration, Arizona State University, Tempe, Arizona, USA. USA.

${ }^{2}$ Department of Geology, Colgate University, Hamilton, New York,

Corresponding author: J. A. McDermott, School of Earth and Space Exploration, Arizona State University, Tempe, AZ 85287, USA. (jenimcd@asu.edu)

(C)2013. American Geophysical Union. All Rights Reserved. 0278-7407/13/10.1002/tect.20018
}

define the southern margin of the Tibetan Plateau, a distinct physiographic feature that marks an abrupt morphologic shift from the expansive, high elevation but low-relief Tibetan Plateau to the high relief and rugged topography of the Himalayan realm. Previous workers noted that this physiographic transition, herein referred to as "physiographic transition 1" or $\mathrm{PT}_{1}$, following Hodges et al. [2001], marked an abrupt change in fluvial character on major river systems that drain transverse to the range from the Tibetan Plateau to the Gangetic Plain and served as the upper boundary to the deep river gorges that characterize the Himalaya [e.g., Wager, 1937]. This change in fluvial character manifests as a series of prominent knickpoints at the approximate location of $\mathrm{PT}_{1}$ across the central Himalaya [e.g., Hodges et al., 2001] with steep river gradients and high local relief continuing $>50 \mathrm{~km}$ to the south where a second morphologic boundary, $\mathrm{PT}_{2}$, marks an abrupt decrease in channel steepness, topographic relief, and hillslope gradient [Seeber and Gornitz, 1983; Hodges et al., 2001; Lavé and Avouac, 2001; Wobus et al., 2003; Hodges et al., 2004; Wobus et al., 2005, 2006b]. This 
$\sim 50 \mathrm{~km}$ wide high relief zone $\sim 100-150 \mathrm{~km}$ north of the active frontal thrusts is seemingly at odds with models that limit active deformation to thrusting along range-front faults and requires an additional mechanism beyond those predicted by simple critical-wedge models [e.g., Dahlen, 1990]. The morphologic transition at $\mathrm{PT}_{2}$ has been interpreted by previous workers to indicate an abrupt increase in uplift and exhumation rate, although the specific mechanism responsible remains controversial [e.g., Cattin and Avouac, 2000; Wobus et al., 2003, 2006b; Bollinger et al., 2006; Robert et al., 2009; Herman et al., 2010]. Following these authors, we examine the structurally higher and more northerly morphologic break at $\mathrm{PT}_{1}$.

[3] Three fundamentally different interpretations of how $\mathrm{PT}_{1}$ was formed and is maintained have been proposed by various researchers. Masek et al. [1994] and Wang et al. [2010] proposed that the current $\mathrm{PT}_{1}$ reflects headward erosional retreat of a steep plateau margin created by Miocene deformation. In contrast, Cattin and Avouac [2000] and Lavé and Avouac [2001] argued that rock uplift patterns in the Himalaya and the resulting landscape morphology do not require active faulting within the range but can be explained by transport of Greater Himalaya rocks over a ramp-flat geometry in the Himalayan Sole thrust; extrapolation of the ramp-flat model to the north predicts a transition similar to $\mathrm{PT}_{1}$ as uplift rates drop with distance north of the midcrustal ramp. A third interpretation was that of Hodges et al. [2001] and Hurtado et al. [2001] who suggested that $\mathrm{PT}_{1}$ may be controlled by movement on young, N-dipping, predominately normal-slip faults.

[4] These models make distinct predictions about the spatial and temporal patterns of exhumation associated with the plateau margin and also imply distinct geomorphic attributes of $\mathrm{PT}_{1}$. In order to test their relative merits, we examine here the thermochronologic, structural, and geomorphic characteristics of the margin in the Nyalam region $\left(\sim 86^{\circ} \mathrm{E}\right)$ of south-central Tibet (Figure 1). To constrain the thermal history of the southern plateau margin and determine if $\mathrm{PT}_{1}$ represents a marked change in exhumation, we employ a multichronometer transect, combining new (U-Th)/He apatite and zircon dates with previously published ${ }^{40} \mathrm{Ar} /{ }^{39} \mathrm{Ar}$ and apatite and zircon fission track data. Additionally, we utilize the well-established relationship between surface morphology and the spatial and temporal distribution of rock uplift [e.g., Wobus et al., 2006a; Ouimet et al., 2009; DiBiase et al., 2010; Kirby and Whipple, 2012] to extract information about differential uplift patterns from the fluvial network and surface landforms. Our analysis
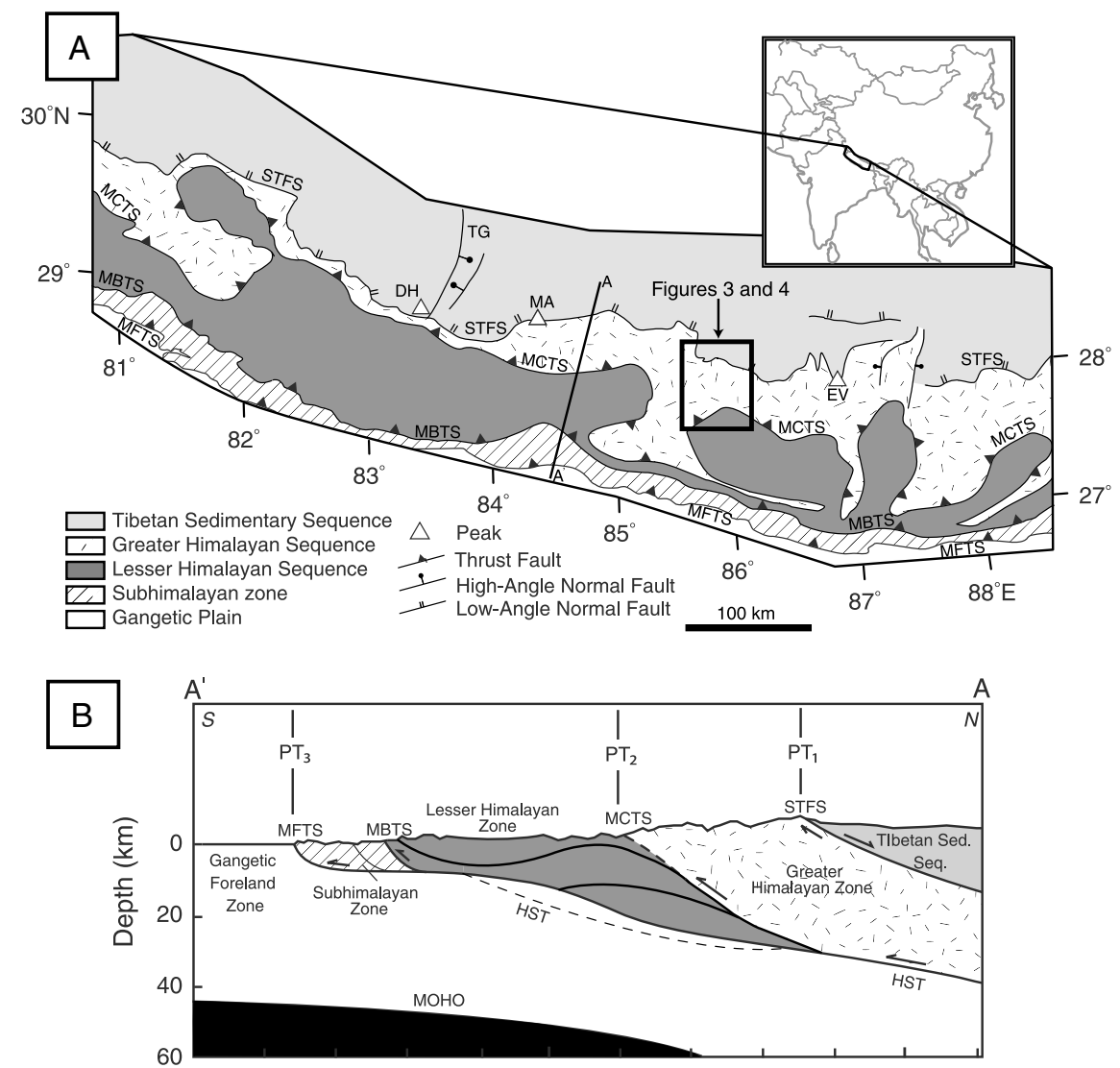

Figure 1. (a) Geologic and structural map of the central Himalaya, after Hodges [2000]. Rectangle shows the extent of Figures 3 and 4. (b) Idealized and simplified cross section across the Himalaya showing the location of previously documented physiographic transitions (basic transect location shown in Figure 1a), modified from Hodges et al. [2001] and Bollinger et al. [2006]. Abbreviations: DH = Dhaulagiri; MA = Machhapuchhare; MBTS = Main Boundary thrust fault; MCTS = Main Central thrust system; MFTS = Main Frontal thrust system; EV = Everest; HST = Himalayan Sole thrust; PT $_{1-3}=$ Physiographic transitions 1-3; STFS = South Tibetan fault system; TG = Thakkhola Graben. 
follows the example of Wobus et al. [2003, 2006b], who used patterns of landscape morphology with emphasis on analysis of river profiles in conjunction with detrital thermochronology to document an abrupt break in exhumation rate across the physiographic transition that marks the southern limit of the High Himalaya $\left(\mathrm{PT}_{2}\right)$. Wobus et al. [2003, 2006b] interpreted this coincidence of a dramatic break in exhumation rate with an abrupt physiographic transition as evidence for active out-of-sequence thrust faulting. Although their structural interpretation has been controversial, the identification of an abrupt change in rock uplift and exhumation rate precisely colocated with the physiographic transition has not been questioned [e.g., Cattin and Avouac, 2000; Bollinger et al., 2006; Robert et al., 2009; Herman et al., 2010] We apply similar tectonic geomorphology tools and a more complete thermochronometric analysis to $\mathrm{PT}_{1}$, specifically to test, in the Nyalam region, the relative merits of the three alternative models for the origin and maintenance of $\mathrm{PT}_{1}$ outlined above.

[5] The Nyalam region and the Bhote Kosi River that cuts across it is an excellent location for this study given that: (1) $\mathrm{PT}_{1}$ is well defined, marked by a dramatic knickpoint on the Bhote Kosi longitudinal river profile and a corresponding abrupt increase in local relief, hillslope gradients, and river channel steepness to the south; (2) a north-south trending transect across $\mathrm{PT}_{1}$ is accessible along the Nepal-Tibet Friendship Highway; (3) the Miocene-aged strand of the STFS is cut by young faults and cannot be contributing to the location and nature of $\mathrm{PT}_{1}$, allowing us to eliminate one potentially contributing influence; and (4) several extant thermochronologic datasets can be combined with our new data to constrain the thermal history of the region over a wide range of temperatures and time scales. Here we ask the questions: Is there a change in exhumation rate and history across $\mathrm{PT}_{1}$ as suggested by landform morphology? What structural configuration and deformation pattern best explains the spatial and temporal exhumation patterns? Can $\mathrm{PT}_{1}$, and the associated exhumation patterns, be accounted for by erosional retreat of a Miocene plateau margin as suggested by some researchers [Masek et al., 1994; Wang et al., 2010] or is an additional mechanism required to explain the thermal and geomorphic character of $\mathrm{PT}_{1}$ ?

\section{Structural and Physiographic Transitions in the Central Himalaya}

[6] The Himalaya are frequently described in terms of tectonostratigraphic units separated by major north-dipping fault systems [e.g., Gansser, 1964; Le Fort, 1975] (Figure 1). The southernmost of these boundaries is the Main Frontal thrust system, which separates the Gangetic Plains of India to the south from the Subhimalayan fold and thrust belt to the north and defines the southern extent of deformation related to the orogenic system. The Main Frontal thrust system is coincident with the southernmost physiographic transition along the Himalaya $\left[\mathrm{PT}_{3}\right.$ of Hodges et al., 2001] (Figure 1B) and is believed to represent the surface expression of the Himalayan Sole thrust, the basal structure along which the majority of Himalayan shortening has been accommodated since at least Pliocene time [e.g., Lavé and Avouac, 2000]. Quaternary activity is obvious from deformed river terraces and alluvial fans [Nakata, 1989; Yeats et al., 1992; Lavé and Avouac, 2000]. The Subhimalayan zone is bound to the north by the Main Boundary thrust system, active in the late Miocene-Pliocene [Meigs et al., 1995; DeCelles et al., 1998a], which serves as the southern boundary to the Lesser Himalayan sequence, an $8-10 \mathrm{~km}$ thick series of metasedimentary phyllites and schists [Gansser, 1964; Colchen et al., 1986; Schelling, 1992]. Across much of the central Himalaya, the Lesser Himalayan sequence is repeated in imbricated thrust sheets of the Lesser Himalayan duplex [Schelling, 1992; Srivastava and Mitra, 1994; DeCelles et al., 1998a, 1998b]. Duplex growth is generally believed to be linked to a crustal ramp on the Himalayan Sole thrust. Sustained growth within the duplex into the Quaternary is evident from sedimentation patterns in the lower Siwalik Group to the south [DeCelles et al., 1998a]. Additionally, a broad pattern of uplift affecting the upper Lesser Himalayan sequence and lower Greater Himalayan sequence as reflected by surface morphology and fluvial profiles has been inferred to represent higher uplift rates [Seeber and Gornitz 1983; Lavé and Avouac, 2001; Wobus et al., 2003, 2006b; Meade, 2010] possibly as a result of duplex growth from the transfer of rocks from the footwall to the hanging wall by underplating [Bollinger et al., 2006].

[7] The upper boundary to the Lesser Himalayan sequence is the Main Central thrust system (MCTS), which lies in the vicinity of the second physiographic transition previously mapped in the Himalaya, $\mathrm{PT}_{2}$ (Figure 2). The MCTS is the structurally highest major thrust system in the Himalayan proper, and the oldest major Cenozoic structure, with an apparent initiation age of $23-20 \mathrm{Ma}$ [Hubbard and Harrison, 1989; Hodges et al., 1996]. The duration of activity on the MCTS is unknown, but Late Miocene-Pliocene displacement has been documented on out-of-sequence faults linked to the system in several locations across the range [Macfarlane et al., 1992; Harrison et al., 1997; Catlos et al., 1999]. Wobus et al. [2006b] showed that although $\mathrm{PT}_{2}$ maps near the MCTS in some locations, the two deviate significantly in others. A distinctive feature of $\mathrm{PT}_{2}$ is that the transition marks a pronounced change in fluvial character on major rivers crossing the transition [Seeber and Gornitz, 1983; Lavé and Avouac, 2001; Wobus et al., 2003, 2006b; Meade, 2010]. The consistent and abrupt shift from steep rivers and a high relief, rocky, landscape north of $\mathrm{PT}_{2}$ to much less steep rivers and low relief, soil mantled topography to the south is thought to indicate an abrupt increase in rock uplift rate north of $\mathrm{PT}_{2}$, although whether this activity is due to surface-breaking structures [e.g., Wobus et al., 2003] or growth of a subsurface duplex [e.g., Bollinger et al., 2006] remains controversial [e.g., Robert et al., 2009; Herman et al., 2010; Godard and Burbank, 2011].

[8] The MCTS serves as the lower boundary to the Greater Himalayan sequence, a laterally continuous sequence of upper-amphibolite facies pelitic, calc-silicate, and augen ortho- gneisses often referred to as the "metamorphic core" of the Himalaya [e.g., Le Fort, 1975]. Farther north, the Greater Himalayan sequence is also bound above by a major fault system, the predominantly low-angle, north-dipping, normal-sense South Tibetan fault system (STFS). The STFS marks a structural, lithologic, and metamorphic discontinuity that extends nearly $2000 \mathrm{~km}$ along strike. Although faults and shear zones with a variety of geometries and kinematic characteristics are featured along the trace of the STFS, there is typically at least one major detachment at this structural level that juxtaposes high-grade metamorphic rocks of 


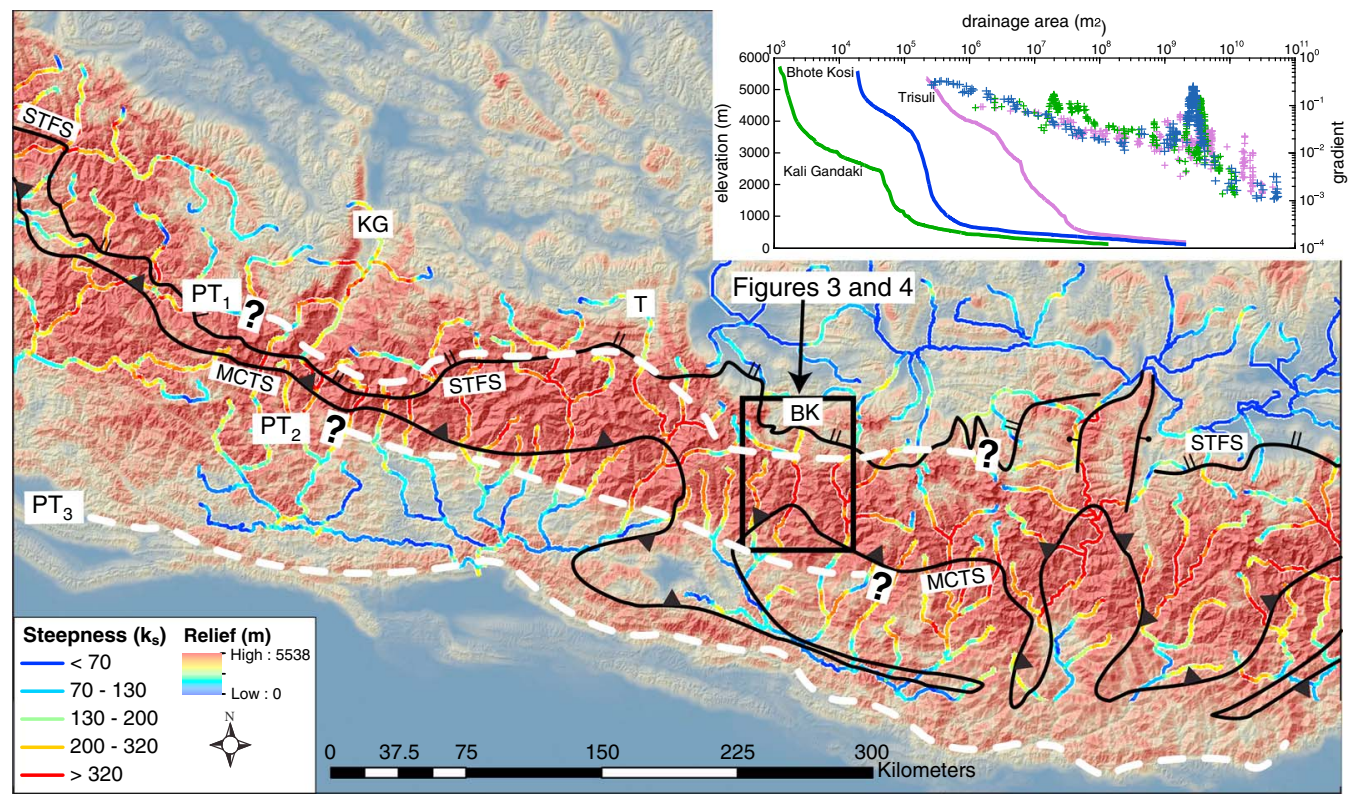

Figure 2. Relief map of the central Himalaya ( $2.5 \mathrm{~km}$ circular window) overlain on shaded relief topography data from $90 \mathrm{~m}$ DEM. Channel steepness $\left(\mathrm{k}_{\mathrm{s}}\right)$ map created following the procedure in Wobus et al. [2006a]. The approximate locations of physiographic transitions 1,2 , and $3\left(\mathrm{PT}_{1}, \mathrm{PT}_{2}\right.$, and $\mathrm{PT}_{3}$ respectively) are indicated by dashed white lines; $\mathrm{PT}_{1}$ and $\mathrm{PT}_{2}$ can be traced bounding the high relief and high channel steepness zones. Note the coincidence of $\mathrm{PT}_{1}$ and $\mathrm{PT}_{2}$ with structures of the South Tibetan fault system (STFS) and Main Central thrust system (MCTS) in some locations but deviating in others. Longitudinal river profiles of transverse Himalayan rivers display prominent knickpoints at the location of $\mathrm{PT}_{1}$ as shown in inset figure. Many of these knickpoints are located near mapped fault traces: the knickpoint on the Kali Gandaki $(\mathrm{KG})$ is located $\sim 10 \mathrm{~km}$ from a young top-to-the-north normal fault (McDermott, J. A., K. V. Hodges, K. X. Whipple, M. C. van Soest, and J. M. Hurtado, Pleistocene North-South extension at the Himalayan crest, Dhaulagiri Himalaya, Nepal, in review), on the Trisuli (T) the knickpoint lies within $20 \mathrm{~km}$ of a mapped fault of unknown significance [Burchfiel et al., 1992], and the knickpoint on the Bhote Kosi (BK) is the focus of this study. Bold box indicates extent of Figures 3 and 4.

the Greater Himalayan sequence in the footwall against the lowgrade to unmetamorphosed passive margin deposits of the Tibetan Sedimentary sequence in the hanging wall to the north. The minimum ages of these detachments have been constrained in some transects by $\mathrm{U}-\mathrm{Pb}$ monazite and zircon dates from deformed and undeformed leucogranite dikes that cut it. For example, $\mathrm{U}-\mathrm{Pb}$ dates from the central Himalaya demonstrate initiation by $22-23 \mathrm{Ma}$ [Harrison et al., 1995; Nazarchuk, 1993; Hodges et al., 1996; Coleman, 1996, 1998; Searle et al., 1999] with ductile activity continuing on some strands until 12-13 Ma [Edwards and Harrison, 1997; Wu et al., 1998]. Early Miocene displacement on these detachments was roughly coeval with principal displacement on the MCTS, providing a mechanism for tectonic exhumation of the Greater Himalayan sequence [Hodges et al., 1992; Hodges, 2000].

[9] Because Early to Middle Miocene activity is wellestablished for the major STFS detachments, many researchers have proposed that the STFS experienced no significant deformation since Middle Miocene time [e.g., Searle and Godin, 2003]. However, it was noted as far back at the late 1980s that many STFS structures post-date the major detachments that mark metamorphic discontinuities between Greater Himalayan and Tibetan Sedimentary sequence rocks [e.g., Burchfiel et al., 1992; Hodges et al., 1996]. The ages of many of these structures are constrained only to be between the Middle Miocene ages of the detachments they sometimes cut and Quaternary glacial landscapes that leave isolated klippen of some of the younger detachments. In at least a few areas, there is direct field evidence for Quaternary slip on some of these structures [e.g., Wu et al., 1998; Hurtado et al., 2001], and it was these observations that prompted Hodges et al. [2001] to hypothesize that $\mathrm{PT}_{1}$ may be localized by Quaternary slip on a long-lived STFS. An alternative interpretation is that the STFS sensu stricto is an exclusively Miocene tectonic element of the Himalaya, but that a distinctive - though roughly colocated - family of normal and transcurrent faults was established in Pliocene-Quaternary time near the Himalayan range crest. Supporting evidence for this interpretation comes from mapping and low-temperature thermochronology in the Annapurna and Dhaulagiri ranges of central Nepal (McDermott J. A. et al., in review), where Pleistocene slip was documented on a $\mathrm{N}$-directed extensional fault at the approximate location of $\mathrm{PT}_{1}$ but structurally above many of the major STFS structures in this area [Brown and Nazarchuk, 1993; Hodges et al., 1996; Godin et al., 1999; Hurtado et al., 2001].

[10] Between $\sim 83^{\circ} \mathrm{E}$ and $86.5^{\circ} \mathrm{E}, \mathrm{PT}_{1}$ defines the crest of the range, separates the high elevation but low-relief Tibetan Plateau from the high relief, rugged topography of the Himalayan realm, and, similar to $\mathrm{PT}_{2}$, is characterized by abrupt river knickpoints that define the southern edge of the central Tibetan Plateau (Figure 2). North of $\mathrm{PT}_{1}$, the 
southern Tibetan Plateau is dominated by E-W extension along $\sim \mathrm{N}-\mathrm{S}$ striking normal faults and related transcurrent faults that strike both NW-SE and NE-SW. Although a single initiation age for E-W extension across the Tibetan Plateau is unlikely, normal faulting on at least some of these faults began by the Middle Miocene [Coleman and Hodges, 1995; Searle, 1995; Blisniuk et al., 2001]. There is, however, no doubt of Quaternary activity; faults display dramatic scarps and triangular facets, and crosscut Quaternary moraine and fluvial deposits [e.g., Armijo et al., 1986; Nakata, 1989]. The southern extent of N-S striking extensional faults is not well constrained and seems to vary along strike in the Himalaya. In the NW Himalaya, N-S striking faults linked to E-W extension have been mapped as far south as the footwall of the MCTS, the lowest structural levels documented in the Himalaya [Hintersberger et al., 2010, 2011]. To the east of $87^{\circ} \mathrm{E}$, the high-angle normal faults that bound the Ama Drime Range cut into structurally high units of the Greater Himalayan Sequence [e.g., Burchfiel et al., 1992], and in western Bhutan numerous N-S striking faults, possibly of strike-slip sense, have been mapped well to the south of the STFS trace [Meyer et al., 2006]. In the central Himalaya between $83^{\circ} \mathrm{E}$ and $86.5^{\circ} \mathrm{E}$, no known faults associated with plateau extension penetrate across $\mathrm{PT}_{1}$, but rather terminate before reaching $\mathrm{PT}_{1}$, or are truncated by $\mathrm{E}-\mathrm{W}$ striking, N-directed extensional faults at that approximate structural level [Hurtado et al., 2001].

\section{Character of the Nyalam Region, South-Central Tibet}

[11] For a closer look at $\mathrm{PT}_{1}$, we elected to explore the geomorphic and structural nature of the region surrounding the Bhote Kosi River between the towns of Nyalam and Zhangmu/Zham near the border of Tibet and Nepal. A geologic transect was studied from immediately north of the border to $8 \mathrm{~km}$ north of Nyalam (Figure 3). South of Nyalam, the Bhote Kosi River flows through one of the most dramatic gorges in the Himalaya; due to the extreme relief within the gorge and the political sensitivity in this border region, our transect was restricted to outcrops along the Friendship Highway. Although this was somewhat limiting, the deep road cuts provide good access to unweathered rocks in the near-vertical cliffs above the river.

\subsection{Geologic Setting}

[12] Our transect lies entirely within the high-grade paraand augen ortho-gneisses of the Greater Himalayan sequence and associated leucogranitic intrusive bodies (Figure 3). The base of that tectonostratigraphic unit, corresponding to the Main Central thrust, lies $\sim 6 \mathrm{~km}$ to the south of the border (the southern limit of our transect). The unit's upper boundary, the STFS, lies $\sim 15 \mathrm{~km}$ to the north of our transect, but we refer in this paper to some thermochronologic data from previous studies that extended farther upsection to the immediate footwall of the STFS [Wang et al., 1998; Wang et al., 2006; Wang et al., 2010]. The southern reach of the field site consists of a

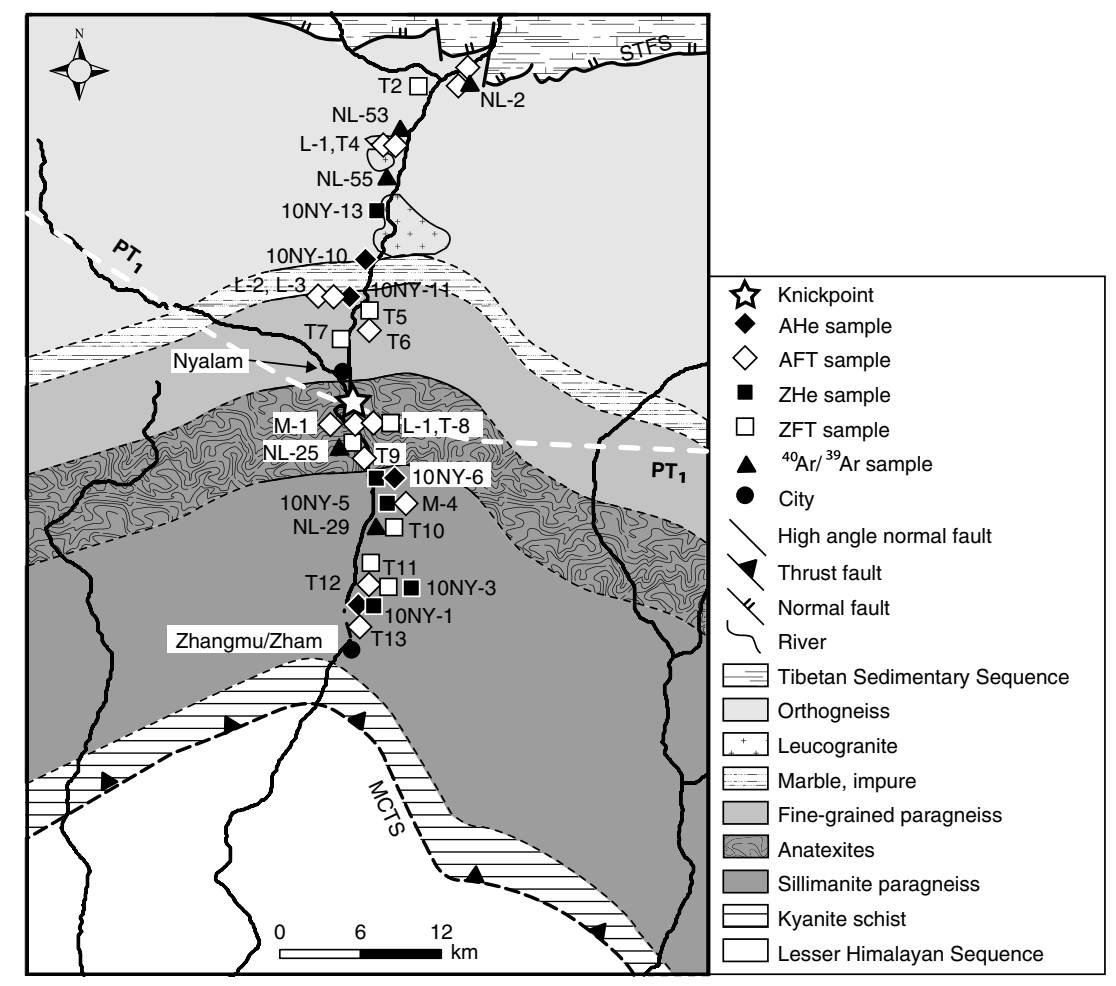

Figure 3. Geologic and structural map of the Nyalam region, modified in part from Maluski et al. [1988], and Wang et al. [2010]. Map shows locations of samples reported for this study as well as samples reported in Wang et al. [1998], Wang et al. [2006], and Wang et al. [2010]. Abbreviations: MCTS = Main Central thrust system; $\mathrm{PT}_{1}=$ Physiographic transition $1 ; \mathrm{STFS}=$ South Tibetan fault system. 
thick unit of sillimanite paragneiss overlain by a fine-grained two-mica gneiss. These basal units display evidence for several ductile deformational events which were contemporaneous with amphibolite facies metamorphism [Hodges et al., 1993]. The most prevalent, and oldest, deformation event, $\mathrm{D}_{1}$, is characterized by a penetrative foliation $\left(\mathrm{S}_{1}\right)$ and associated mineral lineation $\left(\mathrm{L}_{1}\right.$ - defined by the alignment of kyanite, muscovite, and sedimentary quartz aggregates). Shear sense indicators associated with $\mathrm{D}_{1}$ and later ductile deformational events are consistent with top-to-the-south thrusting and have been linked to displacement on the MCTS [Burg et al., 1984; Burchfiel et al., 1992; Hodges et al., 1993]. Near Nyalam, migmatitic gneisses are prevalent and are crosscut by at least two generations of anatectic leucogranites. The structurally lowest leucogranite bodies exhibit weak deformational fabrics consistent with southward thrusting [Burg et al., 1984].

[13] North of our field site, metamorphic units show a greater diversity; in addition to gneissic and leucogranitic lithologies, they include pelitic and psammitic schists, metaquartzites, marbles, and calc-silicate rocks. Leucogranite dikes and sills are prevalent throughout. The basal structure of the STFS in this transect - the Nyalam detachment of Burchfiel et al. [1992] - separates greenschist facies hanging wall Ordovician carbonate rocks from amphibolite facies footwall meta-dolostones, metaquartzites, and psammitic schists of the Cambrian Rouqiecun Group [Myrow et al., 2009]. In the top $\sim 1000 \mathrm{~m}$ of the footwall, $\mathrm{S}_{1}$ has been transposed into a well-developed $\mathrm{S}-\mathrm{C}$ fabric $\left(\mathrm{S}_{3}-\mathrm{C}_{3}\right.$ of Hodges et al. [1993]) with prominent stretching and mineral lineations $\left(\mathrm{L}_{3}\right)$. Shear sense indicators including mica "fish" and asymmetric augen structures are consistent with northward displacement on the overlying STFS [Burg et al., 1984; Burchfiel et al., 1992; Hodges et al., 1993]. Leucogranites cross-cutting the Rouqiecun Group also exhibit planar fabrics and shear sense indicators consistent with north-directed slip [Burg et al., 1984]. Ductile activity on the Nyalam detachment occurred 17-15 Ma [Schärer et al., 1986; Burchfiel et al., 1992; Dougherty et al., 1998], and the associated tectonic denudation resulted in rapid cooling of the footwall sequence in the Middle Miocene [Wang et al., 2006]. Structurally higher strands of the STFS in this area are dissected by north-south striking normal faults of uncertain age and displacement [Burchfiel et al., 1992; Wang et al., 2006], and thus, STF strands have not experienced significant slip in recent times. Despite this, expansive Holocene hot spring deposits have been mapped near the STFS [Zentmyer et al., 2008], suggesting elevated geothermal gradients and active fluid flow along avenues of high hydraulic conductivity along these older fault strands. This hydrothermal activity may be related to active deformation at $\mathrm{PT}_{1}$ as discussed below.

\subsection{Geomorphic Setting}

[14] The region immediately surrounding and to the north of Nyalam, although once glaciated, is relatively flat, with low hillslope gradients, low relief, and low channel gradients. The Bhote Kosi River flows in a wide, alluviated, sometimes braided, channel. Approximately $1 \mathrm{~km}$ south of Nyalam, there is a sudden and dramatic change in the topography (Figure 4a). The local relief increases sharply as the river dives into an exceptionally deep gorge; the river channel narrows, steepens, and becomes entrenched in a bedrock canyon, forming near-vertical cliffs at the river and very

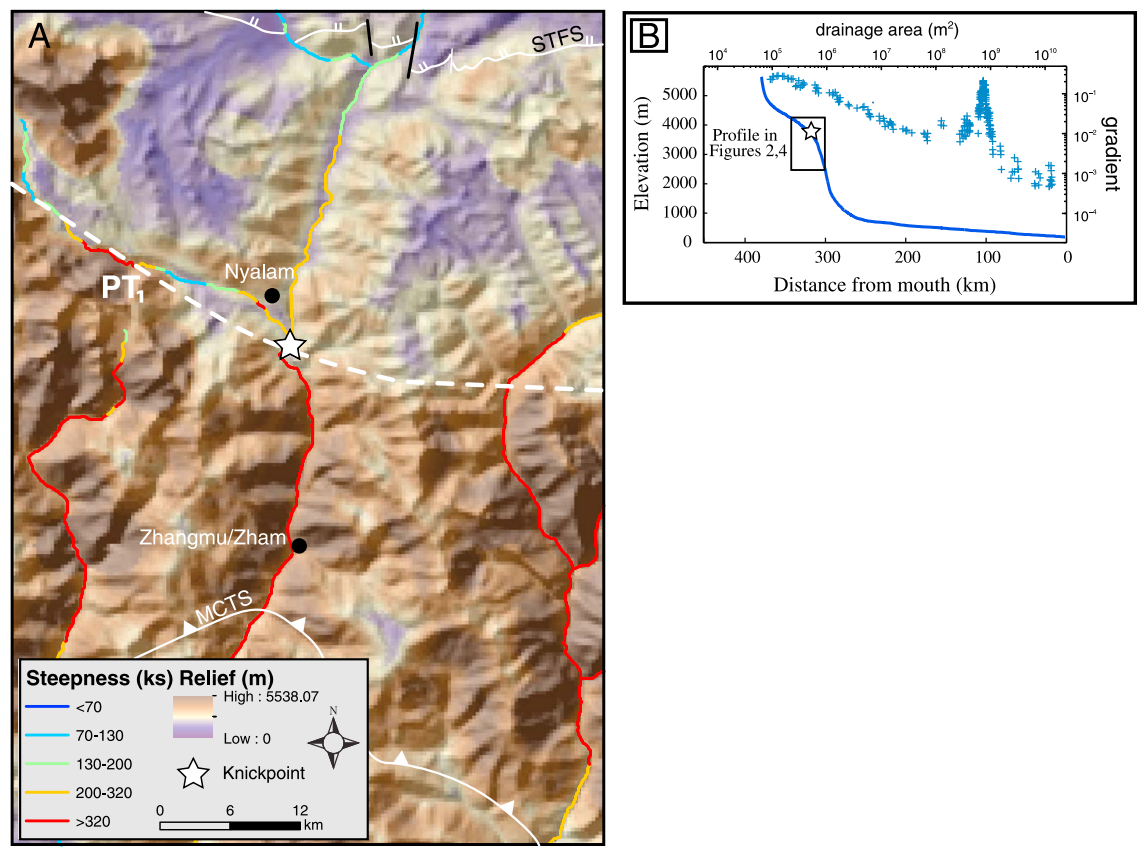

Figure 4. (a) Relief map of the Nyalam region ( $2.5 \mathrm{~km}$ circular window) overlain on shaded relief topography data from $90 \mathrm{~m}$ DEM. River channel steepness calculated as described in text. Abbreviations: MCTS = Main Central thrust system; STFS = South Tibetan fault system. (b) Slope-area data for the Bhote Kosi River (upper right portion of plot) with longitudinal river profile (Lower-left portion of plot). Location of main knickpoint is indicated. 
high hillslope gradients throughout. This change corresponds to a pronounced knickpoint, manifested as a distinct convexity in the longitudinal river profile (Figure $4 \mathrm{~b}$ ); the river and its tributaries remain steep for $\sim 30 \mathrm{~km}$ downstream until it crosses $\mathrm{PT}_{2}$. The high relief zone to the south of the knickpoint is characterized by vegetated yet oversteepened cliffs, accessible only along the road cuts of the Friendship Highway. North of the knickzone, where hillslope gradients are low, the vegetative cover diminishes, but is replaced by thick glacial and fluvial deposits. In the knickzone itself, the steep topography is nearly entirely vegetated, and large, recent landslides cover much of the bedrock.

\section{Thermochronology}

[15] Several thermochronologic studies [Maluski et al., 1988; Wang et al., 1998; Wang et al., 2006; Wang et al., 2010], including this one, have been completed along the river gorge from the Tibet-Nepal border to north of the Miocene-aged strands of the STFS. Here, we combine previous thermochronologic work with our new apatite and zircon (U-Th)/He cooling ages to define the thermal histories of rocks on either side of the physiographic transition.

\subsection{Previous Thermochronologic Work}

[16] Wang et al. [2010] synthesized the results of several studies in the Nyalam region [Wang et al., 1998; Wang et al., 2006; Wang et al., 2010] to produce a densely sampled ${ }^{40} \mathrm{Ar} /{ }^{39} \mathrm{Ar}$ biotite (BAr), apatite fission track (AFT), and zircon fission track (ZFT) thermochronologic transect extending from the STFS in the north to the Tibet-Nepal border at Zhangmu/Zham to the south (Figure 3). Maluski et al. [1988] and Wang et al. [2006] both reported BAr cooling ages from along similar transects; however, the data sets contradict each other south of the knickpoint. The results of Maluski et al. [1988] show a younging trend in cooling ages from 16 to $15 \mathrm{Ma}$ north of Nyalam to less than $6 \mathrm{Ma}$ near the Nepal border region; Wang et al. [2006] reported no such trend but instead showed that cooling ages consistently cluster around 16-14 Ma along the entire transect (Figure 5). We make no attempt to resolve this conflict in the current work, but include the ${ }^{40} \mathrm{Ar} /{ }^{39} \mathrm{Ar}$ cooling age data from Wang et al. [2006] in our analysis as their work utilizes more up to date analytical techniques. The Wang et al. [2006] data reveal no discernable variation in BAr cooling ages along the transect, indicating that the entire Greater Himalayan sequence homogeneously cooled through the ${ }^{40} \mathrm{Ar} /{ }^{39} \mathrm{Ar}$ biotite closure temperature $\left(\sim 300^{\circ} \mathrm{C}\right.$; Harrison et al. [1995]) between 16 and $14 \mathrm{Ma}$. These data are consistent with BAr data from the Greater Himalayan sequence to the west in central Nepal [Vannay and Hodges, 1996; Coleman, 1998].

[17] The results of two ZFT and AFT studies were summarized in Wang et al. [2010]. These data show a cooling age gradient in both thermochronometers, with Middle Miocene ages in the immediate footwall of the STFS younging to Plio-Pleistocene ages in the south (Figure 5). These data are not easily explained by the known displacement histories of the MCTS and the STFS, and Wang et al. [2010] interpreted the cooling age patterns as recording climate-enhanced erosion of a topographic front that they argue was located $20-30 \mathrm{~km}$ to the south of its current position in the Late Miocene.

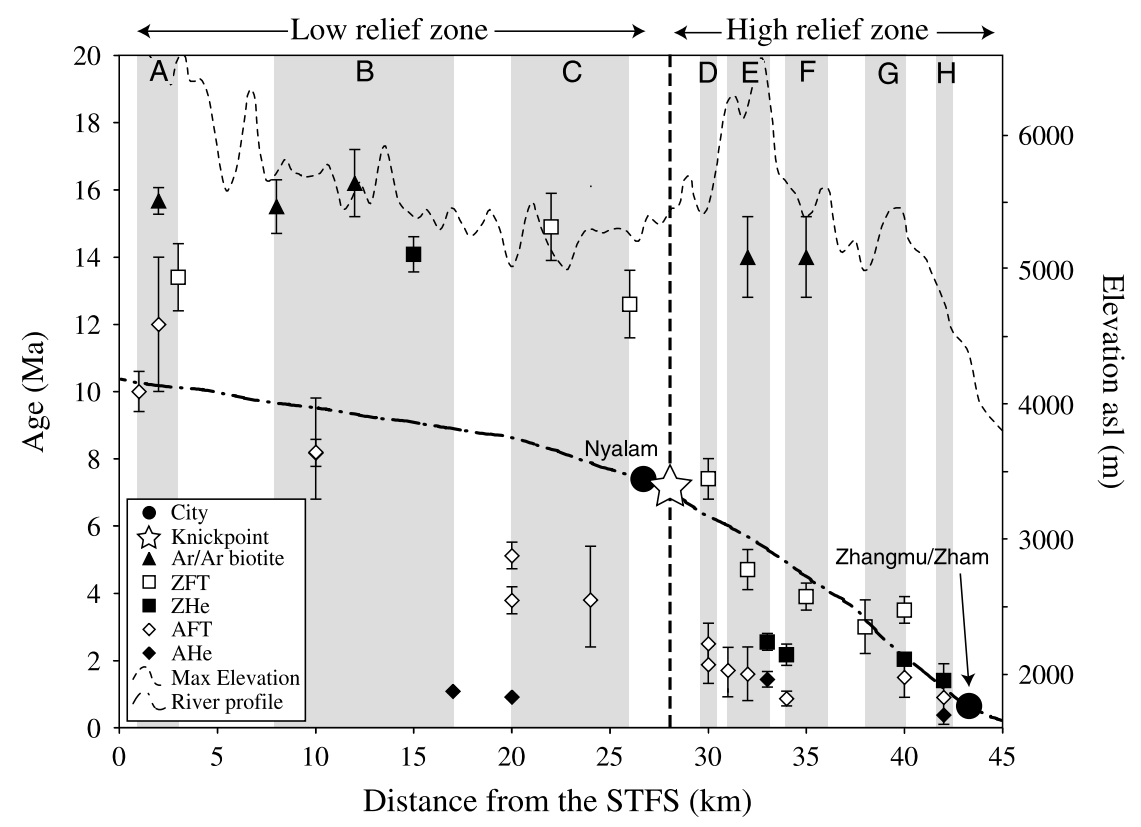

Figure 5. Plot of cooling ages versus distance for the Nyalam region. Cooling age data from this study, Wang et al. [1998], Wang et al. [2006], and Wang et al. [2010]. Errors plotted at 2SE. Vertical dashed line denotes the change from low relief to high relief and also coincides with the knickpoint. Vertical gray boxes $(\mathrm{a}-\mathrm{h})$ correspond to the spatial zones in Figure 6. Abbreviations: AFT $=$ apatite fission track; $\mathrm{AHe}=(\mathrm{U}-\mathrm{Th}) / \mathrm{He}$ apatite; STFS $=$ South Tibetan fault system; ZFT $=$ zircon fission track; ZHe = (U-Th)/He zircon. 
[18] ZFT cooling ages show a sharp change in cooling age distribution at the location of $\mathrm{PT}_{1}$ (Figures 3 and 5). North of $\mathrm{PT}_{1}$, ZFT cooling ages are generally Middle Miocene and show no relationship with elevation, while south of the transition, the ZFT ages are Pliocene and show a strong linear trend with elevation; this trend is consistent with an apparent exhumation rate of $0.38 \mathrm{~mm} / \mathrm{yr}$ [Wang et al., 2010]. AFT cooling ages also become younger to the south, but do not exhibit the sharp cooling age discontinuity at $\mathrm{PT}_{1}$ observed in the ZFT dataset.

\subsection{New Zircon and Apatite (U-Th)/He Cooling Ages}

[19] To further constrain the thermal history of the Nyalam region, and to unlock the most recent exhumation pattern, apatite and zircon (U-Th)/He thermochronologic transects (AHe and $\mathrm{ZHe}$, respectively) were completed along the Bhoti Kosi River gorge, starting just north of the TibetNepal border to the south (at Zhamgmu/Zham, see Figure 3) and continuing to $\sim 8 \mathrm{~km}$ north of Nyalam.

\subsubsection{Methods}

[20] Apatite and zircon were separated from bedrock samples using standard gravimetric and magnetic techniques prior to hand picking under a binocular microscope. Single euhedral and inclusion-free grains of either apatite or zircon were loaded into $\mathrm{Nb}$ microcrucibles and placed into a stainless steel sample holder for ${ }^{4} \mathrm{He}$ measurements on an ASI Alphachron in the Noble Gas Geochronology and Geochemistry Lab $\left(\mathrm{NG}^{3} \mathrm{~L}\right)$ at Arizona State University. Three age standards (Durango apatite for apatite samples and Durango apatite and Fish Canyon zircon for zircon samples) and two blanks (empty Pt or $\mathrm{Nb}$ tubes) together with 20 unknowns were loaded on the sample holder for each Alphachron run. After pumping down the laser chamber to ultra-high vacuum, helium was extracted from each sample using a $980 \mathrm{~nm}$ diode laser operated at $45 \mathrm{~W}$. The gas was spiked with ${ }^{3} \mathrm{He}$ and cleaned of any reactive gases by exposure to a hot SAES NP-10 getter. The purified gas was analyzed on a Balzers Prisma QMS 200 quadrupole equipped with a Channeltron electron multiplier.

[21] After completion of the Alphachron run, unknowns, age standards, and blanks were extracted from the vacuum system and prepared for isotope dilution analysis. Encapsulated apatite grains were dissolved using $25 \mu \mathrm{l}$ of $50 \%$ $\mathrm{HNO}_{3}$ containing $\sim 15 \mathrm{ng}$ of ${ }^{235} \mathrm{U}$ and $\sim 5 \mathrm{ng}$ of ${ }^{230} \mathrm{Th}$ (used as a $U$ and Th spike), following the procedure of Evans et al. [2005]. Zircon dissolution required concentrated HF, $\mathrm{HNO}_{3}$ (also containing a ${ }^{235} \mathrm{U}$ and ${ }^{230} \mathrm{Th}$ spike), and $\mathrm{HCl}$ and was completed with Parr digestion vessels to reach high temperature and pressure as outlined by Reiners [2005]. Finally, $\mathrm{U}$ and $\mathrm{Th}$ measurements were made on an inductively coupled, plasma-source mass spectrometry using a Thermo X-series quadrupole instrument in the W.M. Keck Foundation Laboratory for Environmental Geochemistry at Arizona State University. A more detailed description of $\mathrm{AHe}$ and $\mathrm{ZHe}$ methods used in this study can be found in van Soest et al. [2011].

\subsubsection{Results}

[22] Euhedral apatite and zircon grains suitable for (U-Th)/ He work were rare in many of the samples collected in the Nyalam region. Nonetheless, we report here five $\mathrm{ZHe}$ and four $\mathrm{AHe}$ cooling ages. Only one sample collected north of $\mathrm{PT}_{1}$ contained a zircon suitable for $\mathrm{ZHe}$ analysis; it yielded a date of 14.08 with an analytical imprecision (at the $2 \sigma$ level) of $0.52 \mathrm{Ma}$. This date contrasts sharply with $\mathrm{ZHe}$ dates for samples collected south of $\mathrm{PT}_{1}$. Mean dates for all other samples (based on analyses of five grains from each zircon sample and five to six grains from each apatite sample, unless otherwise noted, quoted with an uncertainty corresponding to two standard errors of the mean, or $2 \mathrm{SE}$ ) range from $2.55 \pm 0.11$ to $1.415 \pm 0.049 \mathrm{Ma}$ (Tables $1 \mathrm{a}$ and $1 \mathrm{~b}$; Figure 5). AHe cooling ages below $\mathrm{PT}_{1}$ are Pleistocene, with dates of 1.44 $\pm 0.10 \mathrm{Ma}$ and $0.380 \pm 0.045(2 \sigma)$. The latter date is reported on only one grain; two additional euhedral grains were analyzed but their calculated dates (1.73 and 4.08 Ma) are older than ZHe dates from the same sample, suggesting the presence of high U-Th microinclusions which can lead to an overestimation of cooling age [e.g., Vermeesch et al., 2007]. Notably, AHe cooling ages from above $\mathrm{PT}_{1}$ are also Pleistocene $(1.079 \pm 0.018 \mathrm{Ma}$ and $0.914 \pm 0.016 \mathrm{Ma})$ (Figure 5).

\section{Discussion of Low-Temperature Thermochronologic Data}

[23] The combined data sets of Wang et al. [1998], Wang et al. [2006], and Wang et al. [2010] with the new (U-Th)/ He cooling ages reported in the current study result in a densely sampled transect across $\mathrm{PT}_{1}$ using five different thermochronometers, allowing us to examine the thermal history of the region from $\sim 300^{\circ} \mathrm{C}$ to $\sim 70^{\circ} \mathrm{C}$, over a time period of $>16$ million years. Although this is a valuable dataset, interpretation of the thermal history from it is complicated by the fact that the transect covers a distance of $45 \mathrm{~km}$, an elevation change of over $2.5 \mathrm{~km}$, and a region with variable topographic relief. Plotting the Nyalam combined thermochronologic data in traditional age-elevation or age-distance plots (Figure 5) is not particularly revealing. A definitive interpretation of these plots is not possible as they undoubtedly conflate temporal and spatial variations in both exhumation rate and geothermal gradient.

[24] With data from five different thermochronometers arrayed along the transect, however, we can isolate spatial and temporal effects by constructing thermal histories at various positions along the transect as allowed by the distribution of data. To do this, we divided the transect into eight spatial zones that each encompass data from three to five different chronometers (Figure 5). We then estimated the cooling rate with time for each spatial zone using given average closure temperature (Table 2), cooling age for each chronometer, and simple piecewise linear regression, extrapolating to zero age at $5^{\circ} \mathrm{C}$ (our best estimate for the average surface temperature at the elevations of interest) (Figure 6). We report cooling rates, $\Delta \mathrm{T} / \Delta \mathrm{t}\left({ }^{\circ} \mathrm{C} / \mathrm{My}\right)$, rather than the traditional exhumation rates, $\Delta \mathrm{z} / \Delta \mathrm{t}(\mathrm{km} / \mathrm{Ma})$, as the later require a priori knowledge of the geothermal gradient, which may vary in space and time along the transect. To aid with spatial interpretation of these cooling histories, we plot the cooling rates determined for each zone in five different time periods as a function of position along the transect (Figure 7).

[25] The results show higher cooling rates $\left(\sim 40^{\circ} \mathrm{C} / \mathrm{My}\right)$ in the immediate footwall of the STFS in the Middle Miocene (zones $\mathrm{A}$ and $\mathrm{B}$ ), consistent with rapid exhumation of 
MCDERMOTT ET AL.: ACTIVE N-S EXTENSION AT HIMALAYAN CREST

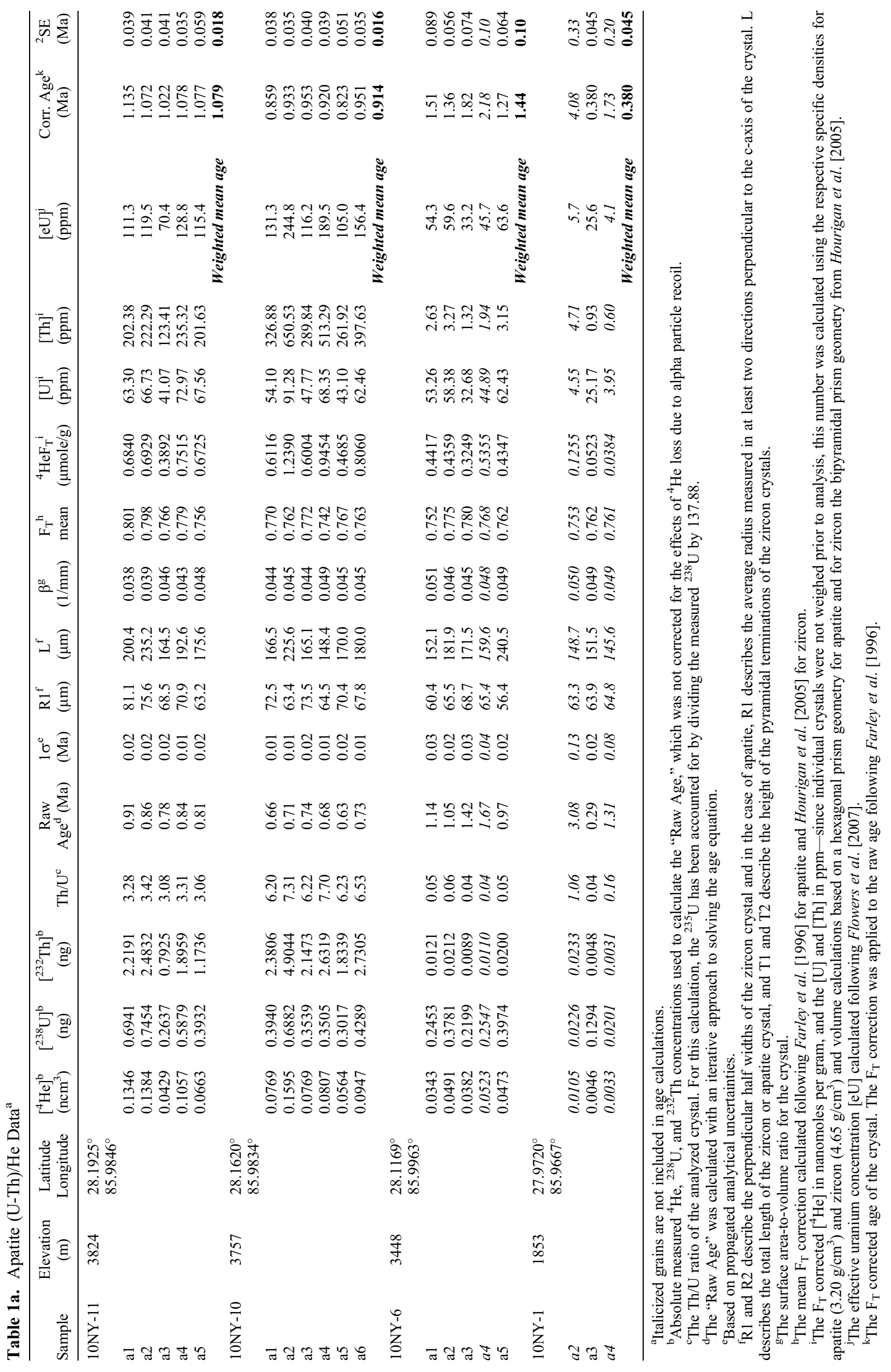


MCDERMOTT ET AL.: ACTIVE N-S EXTENSION AT HIMALAYAN CREST

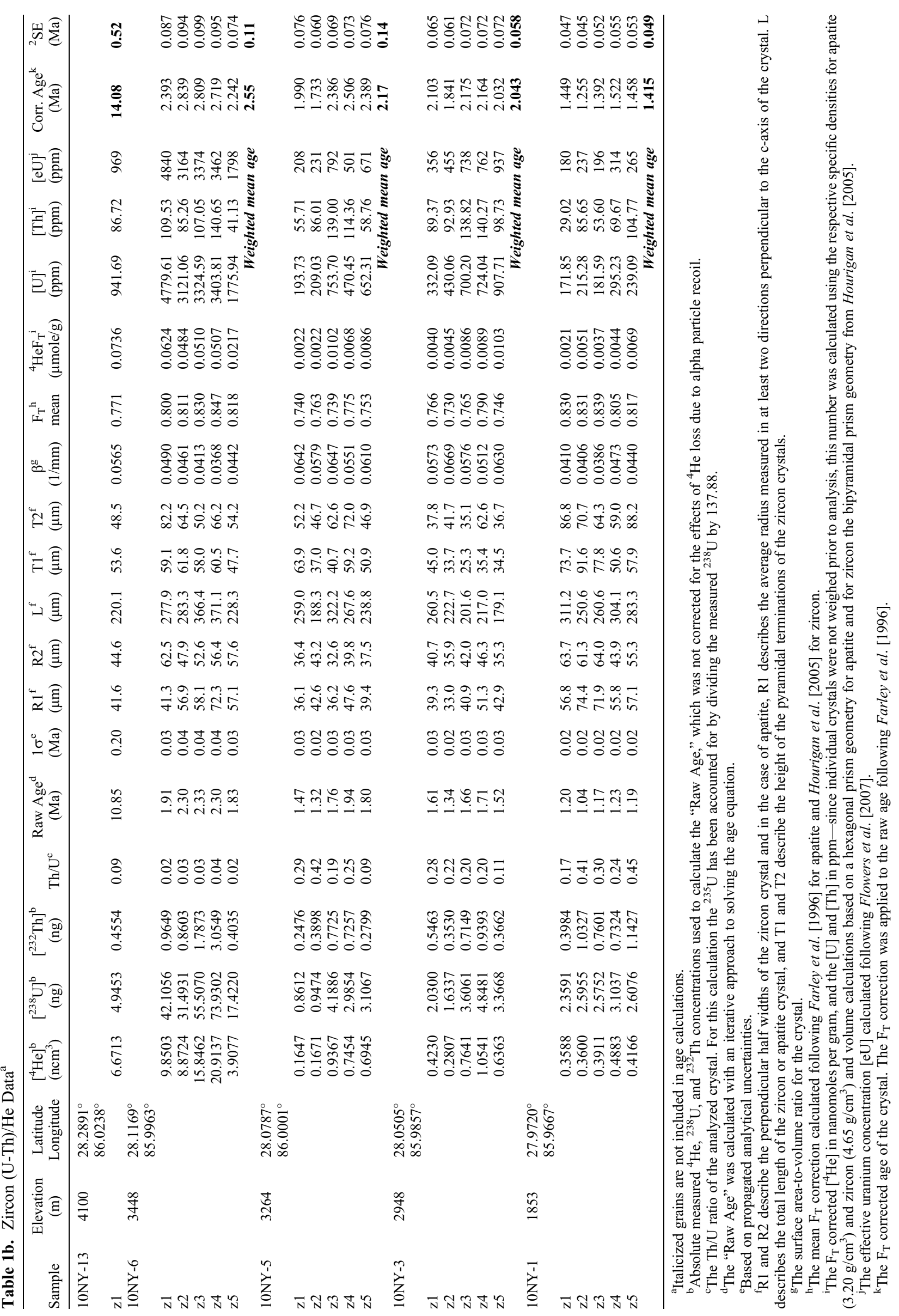


Table 2. Chronometer Closure Temperatures Used

\begin{tabular}{llcl}
\hline Isotopic System & Mineral & $\operatorname{Tcb}\left({ }^{\circ} \mathrm{C}\right)$ & \multicolumn{1}{c}{ Reference } \\
\hline (U-Th)/He & Apatite & 70 & Farley $[2000]$ \\
& Zircon & 190 & Reiners $[2004]$ \\
Fission track & Apatite & 110 & Brandon et al. [1998] \\
& Zircon & 220 & Brandon et al. $[1998]$ \\
40AR/39Ar & Biotite & 300 & Harrison et al. $[1985]$ \\
\hline
\end{tabular}

footwall rocks (Figure 7). The cooling rates in these zones diminish with time (to $\sim 10^{\circ} \mathrm{C} / \mathrm{My}$ ), likely reflecting the cessation of major activity on the Miocene STFS, consistent with the findings of Wang et al. [2010]. Cooling rates across the entire region remain low, both north (zones A-C) and south (zones D-F) of the knickpoint, at $\sim 10^{\circ} \mathrm{C} / \mathrm{My}$ until $<4 \mathrm{Ma}$, when a dramatic increase in cooling rate occurs in all zones south of $\mathrm{PT}_{1}$ (zones $\mathrm{D}-\mathrm{F})$. Note that zones $\mathrm{G}$ and $\mathrm{H}$ record only this young rapid cooling (Figure 6 ). Between $\sim 4$ and $\sim 1 \mathrm{Ma}$, cooling rates remain at $\sim 10^{\circ} \mathrm{C} / \mathrm{My}$ above the knickpoint, but increase to $\sim 50^{\circ} \mathrm{C} / \mathrm{My}$ just to the south, and reach $>120^{\circ} \mathrm{C} / \mathrm{My}$ at the southern edge of the transect (Figure 6 and 7). Afterwards $(<1 \mathrm{Ma})$, rapid cooling is recorded north of the knickpoint by two young AHe ages, 8 and $11 \mathrm{~km}$ north of $\mathrm{PT}_{1}$ (Figures 5 and 7).

[26] This cooling rate pattern is consistent with significant slip on the mapped STFS (Figure 3) ceasing in the Late Miocene, at least with respect to displacement large enough to be reflected in the low-temperature thermochronologic data. At $\sim 3.5 \mathrm{Ma}$, cooling rate increases abruptly south of $\mathrm{PT}_{1}$, requiring a mechanism capable of producing distinctly different cooling histories across a narrow zone.

[27] Most of the thermochronologic data are consistent with the interpretation that $\mathrm{PT}_{1}$ separates areas of differential exhumation since $\sim 3.5 \mathrm{Ma}$. The two $\sim 1 \mathrm{Ma}$ AHe ages north of the knickpoint (Figures 5 and 7) are exceptions. These two data points are also distinct from the rest of our dataset in that replicate analyses on five and six grains, respectively,
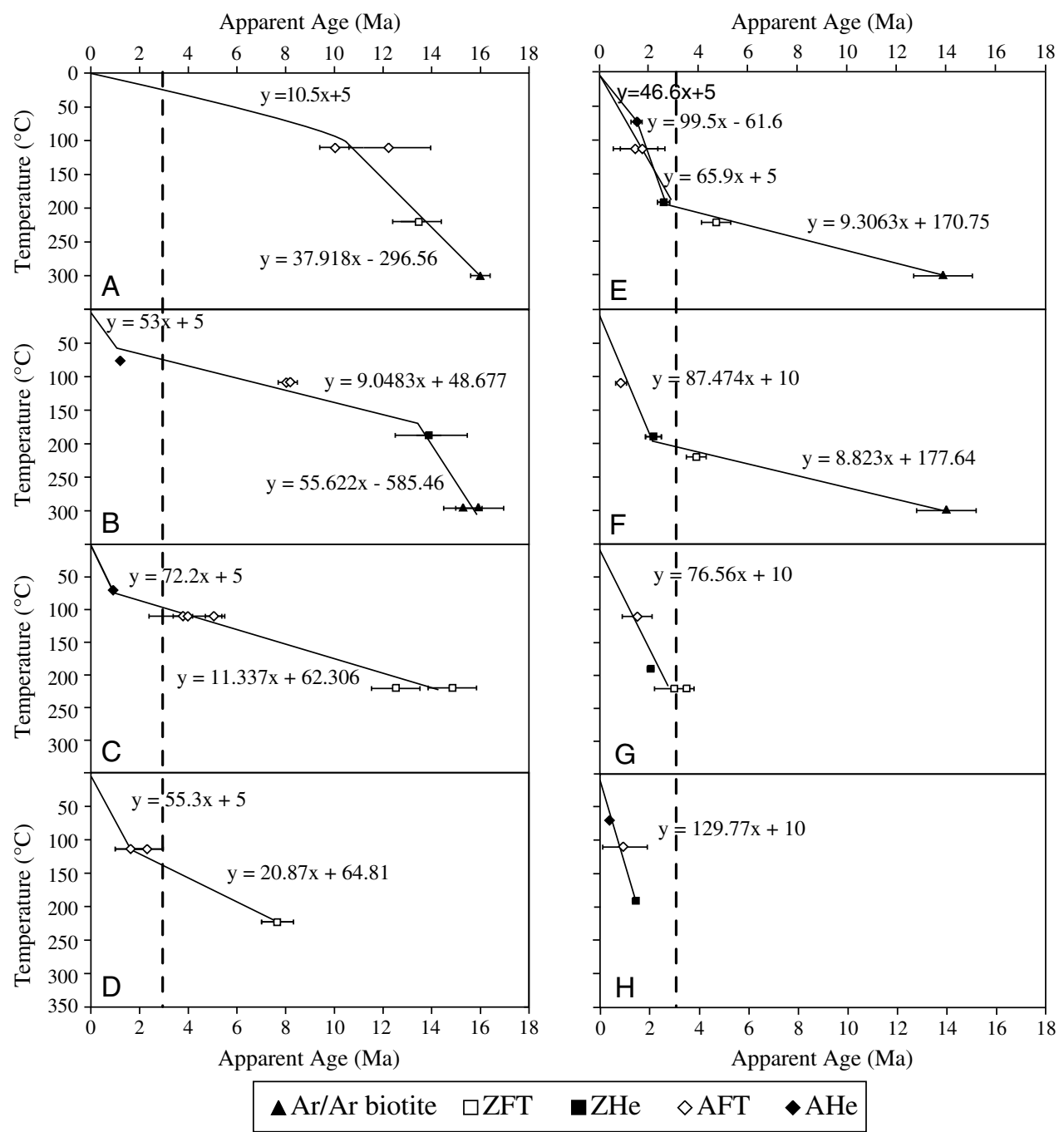

Figure 6. Cooling histories (cooling age versus closure temperature) for the individual spatial sections indicated in Figure $5(\mathrm{a}-\mathrm{h})$. Vertical dashed line marks the time of general cooling rate change at $\sim 3.5$ Ma as discussed in the text. Cooling age data from this study, Wang et al. [1998], Wang et al. [2006], and Wang et al. [2010]. Errors plotted at 2SE. Slopes (cooling rate) for each temporal section are plotted in Figure 7. 


\section{MCDERMOTT ET AL.: ACTIVE N-S EXTENSION AT HIMALAYAN CREST}
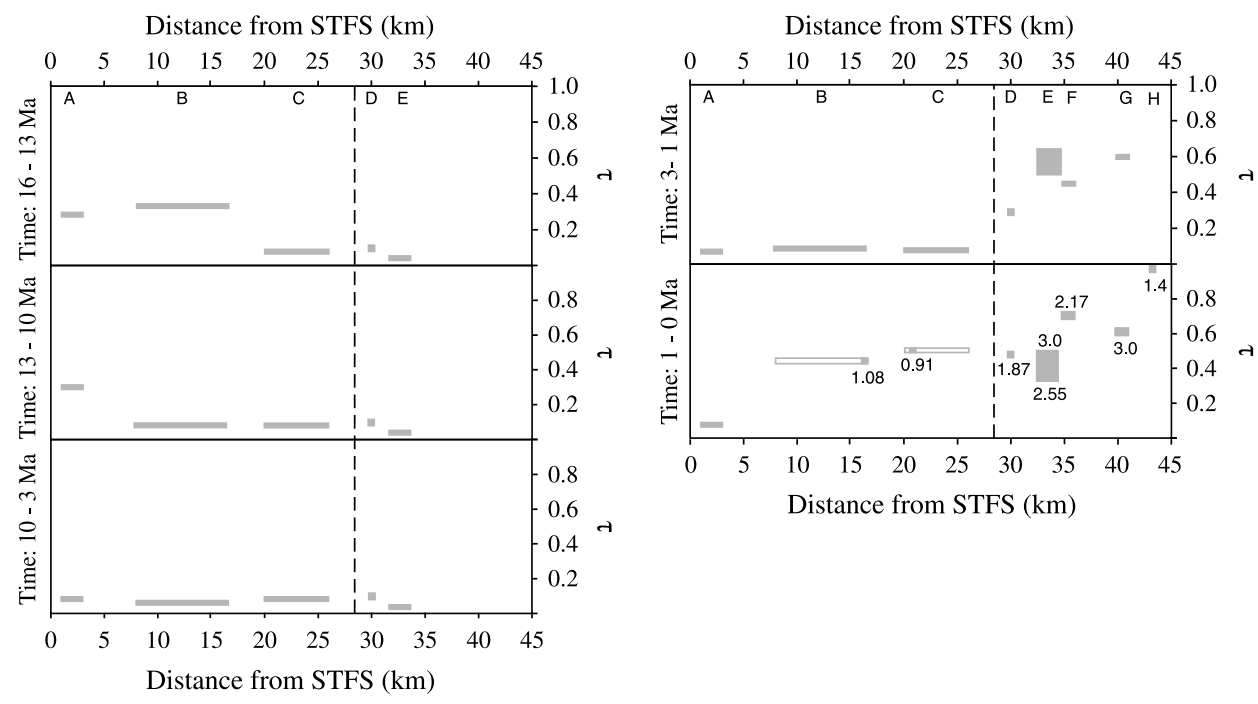

Figure 7. Cooling rates for each spatial section (compiled from data in Figure 6) through time. Cooling rates are nondimensionalized $(\tau)$ for ease of plotting comparison. Displacement on the STFS in the Middle Miocene can be seen in the $16-13 \mathrm{Ma}$ and $13-10$ ma time slots, while displacement likely related to the normal faulting described in the text is illustrated after $\sim 3.5 \mathrm{Ma}$. Cooling rates for "E" can be calculated several ways after $3 \mathrm{Ma}$ (see Figure 6 "E"), and therefore a range of possible rates are shown. Since the 1-0 Ma cooling rates for "B" and " $\mathrm{C}$ " are based solely on the AHe ages, the specific location of those samples is highlighted within the spatial slots. Numerical values in the final frame (1-0 Ma) represent the time of the significant cooling change in millions of years (see Figure 6 for more details).

yield by far the most precise ages ( $\sim 1 \%$ uncertainty) we obtained. The internal consistency of the rest of the data and the different character of these precise ages lead us to question whether these samples faithfully reflect cooling due to exhumation or some other near-surface resetting event, such as the circulation of hydrothermal fluids through the upper crust [Whipp and Ehlers, 2007]. AHe dates are especially susceptible to resetting or partial resetting due to the high diffusivity of $\mathrm{He}$ in apatite at relatively low temperatures, and the more precise ages may reflect the effects of a reheating event. As noted earlier, hot spring deposits have been documented to the north of the AHe samples [Zentmyer et al., 2008], although we were unable to conduct a thorough search for travertine at the sample sites due to the political sensitivity of the region, it is possible the samples were exposed to hydrothermal fluids. If so, the young AHe dates may reflect resetting by hydrothermal alteration rather than cooling through a closure isotherm as a result of exhumation. Alternatively, the increase in cooling rate since $\sim 3.5 \mathrm{Ma}$ south of the knickpoint at $\mathrm{PT}_{1}$ could, at least in part, result in an elevated geothermal gradient for the region; the young $\mathrm{AHe}$ dates to the north of $\mathrm{PT}_{1}$ could reflect this increase in geothermal gradient rather than simply an increase in exhumation rate, resulting in a lack of apparent difference in exhumation rate on either side of the physiographic transition in the last 1 million years.

[28] To make further progress, we outline the distinct, testable predictions of three alternate models and turn to the tools of tectonic geomorphology to help evaluate their relative merits.

\section{Testing Alternate Models}

[29] As noted earlier, three different models for the formation and maintenance of $\mathrm{PT}_{1}$ have been proposed:
(1) erosional retreat of the Miocene-age tectonic plateau margin [Masek et al., 1994; Wang et al., 2010], (2) uplift over a ramp in the Himalayan Sole thrust [Lavé and Avouac, 2001], and (3) active normal-sense displacement at $\mathrm{PT}_{1}$. All three models present viable mechanisms for the development of a well-defined morphologic plateau break as well as predict higher exhumation rates to the south of the southern plateau margin relative to rates to the north on the physiographic plateau, and thus, are consistent with the general decrease in low-temperature thermochronologic cooling ages seen in the data presented here. However, where that change in exhumation occurs relative to the morphologic break, and how that change manifests itself (i.e., transitional or abrupt) is unique for each model, allowing for the evaluation of each model within the context of the observed geomorphic, thermal, and structural setting at $\mathrm{PT}_{1}$. By combining quantitative measures of the geomorphic character of $\mathrm{PT}_{1}$ (locally and regionally) with the thermal histories determined above, we can more definitively constrain the erosional and tectonic history of the Nyalam region along our transect down the Bhote Kosi River.

[30] The first model proposes that the steep topographic front of the Himalaya existing today can be explained by erosional retreat of a mountain front constructed in the Miocene located well to the south of the current topographic break [Masek et al., 1994; Wang et al., 2010]. Orographic effects focus precipitation, and thus erosion, along the windward side of the topographic high, removing mass and resulting in a leeward migrating plateau margin. As orographic precipitation is slope dependent, the majority of erosive power is concentrated at the lower slopes near the base of the topographic margin, resulting in an oversteepened margin upon retreat [Masek et al., 1994]. In this model, the topographic break at $\mathrm{PT}_{1}$ marks the boundary 
between high erosion rates to the south driven by climatically driven erosion in the model of Wang et al. [2010] and low erosion rates in the rain shadow on the plateau. This should manifest as an abrupt upstream (northward) decrease in channel steepness of rivers flowing across the transition because there is a strong relationship between channel steepness $\left(\mathrm{k}_{\mathrm{s}}\right)$ - a metric of channel slope corrected for drainage area-and erosion rate [e.g., Wobus et al., 2006a; Ouimet et al., 2009; Cyr et al., 2010; DiBiase et al., 2010; Kirby and Whipple, 2012]. This pattern of an abrupt shift in channel steepness across the topographic margin is evident in the fluvial signature of the trans-Himalayan rivers at $\mathrm{PT}_{1}$ (Figures 2 and 4). Additionally, as predicted by the model, and consistent with the model of Wang et al. [2010], we see a change is cooling ages across the margin; below $\mathrm{PT}_{1}$, where erosion rates, and thus exhumation, should be high, cooling ages are young while above $\mathrm{PT}_{1}$, the area yet to be affected by an erosional retreating margin, cooling ages are significantly older.

[31] The margin retreat model, however, does not predict coincidence between the current knickpoint location and the cooling age discontinuity, but rather predicts a lag between the cooling age break and the topographic break to allow for sufficient differential erosional exhumation to reset the thermochronometer of interest. This lag space is inherent in the use of low-temperature thermochronometry for evaluation of exhumation and is independent from the process of exhumation, be it tectonic, climatic or erosionally driven. In order for an increase in erosion rate to be reflected in cooling ages, total erosion must be sufficient to exhume rocks from the depth of closure temperature $(\sim 3 \mathrm{~km}$ for $\mathrm{AHe}$ and 7.5 for ZHe with an average geothermal gradient of $25^{\circ} \mathrm{C}$ ). Even considering an increase in the geothermal gradient to as much as $50^{\circ} \mathrm{C}-75^{\circ} \mathrm{C} / \mathrm{km}$ as a result of isotherm advection, at least $1 \mathrm{~km}$ must be eroded before low-temperature thermochronology will record an increase in erosion rate. By definition, for a retreating erosional knickpoint, differential erosion is zero at the knickpoint and increases with distance downstream as erosional relief increases. Consequently, even in regions with rapid erosion-induced exhumation, the thermochronologic cooling age discontinuity will not coincide with the current location of a migrating knickpoint associated with escarpment retreat, but rather, will map at a point downstream where the total amount of erosion is sufficient to "reset" the chronometer of interest - at least $20 \mathrm{~km}$ in this case (see Figures 5 and 8). Thus, this model is not consistent with the observed increase in exhumation rate as recorded in thermochronometers within $2 \mathrm{~km}$ of the knickpoint (where only 200-300 m of differential erosion would be implied by the retreating knickpoint model). The mapped coincidence of the thermochronologic cooling age discontinuity with the abrupt morphologic change is inconsistent with erosional retreat as the dominant factor setting and maintaining $\mathrm{PT}_{1}$.

[32] The second model derives from the work of Lavé and Avouac [2001], who deduced uplift patterns by examining the incision histories and present-day longitudinal profiles of major transverse rivers in the central Himalaya (where uplift $\approx$ incision is assumed). They found that, when generalized to fit compiled data from five major rivers, the inferred uplift pattern was roughly consistent with rock uplift across a ramp on the Himalayan Sole thrust (ramp-flat

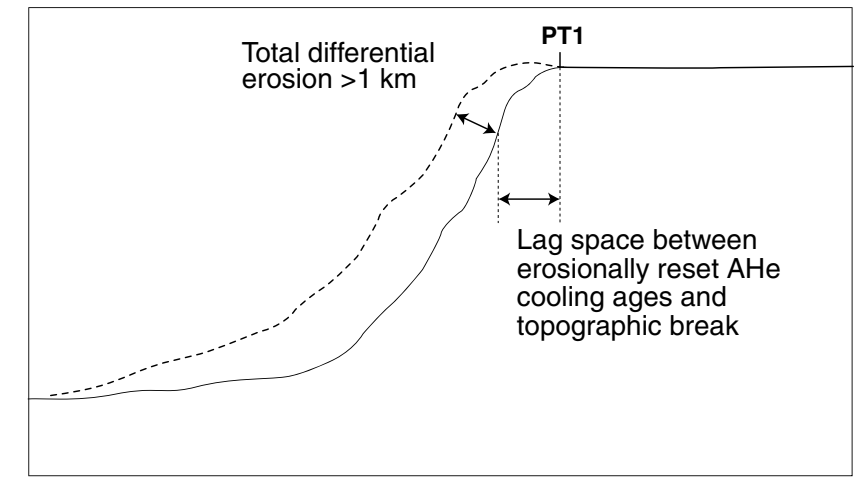

Figure 8. Cartoon illustrating the predicted lack of coincidence between the topographic margin break and the thermochronologic cooling age break for a simple erosional margin retreat model.

model of Cattin and Avouac [2000]), such that active faulting is not required to explain the uplift pattern predicted by the river profiles. A closer look at the Bhote Kosi, however, reveals that the channel steepness pattern is not consistent with the uplift pattern implied by the canonical ramp-flat model (Figure 9). The ramp-flat model predicts a gradual decrease in uplift rate to the north and does not explain the abrupt increase in channel steepness at the top of the knickzone - the match between uplift patterns implied by the geomorphology and predicted by the ramp-flat model claimed by Lavé and Avouac [2001] appears to be an artifact of the stacking of five river profiles that each imply different uplift patterns with abrupt increases occurring at different positions along their composite profile. While the incision/ uplift suggested by the fluvial character of the lower reach of the Bhote Kosi is consistent with uplift over a midcrustal ramp, the abrupt decrease in channel steepness at the location of $\mathrm{PT}_{1}$ is not and suggests that an additional mechanism

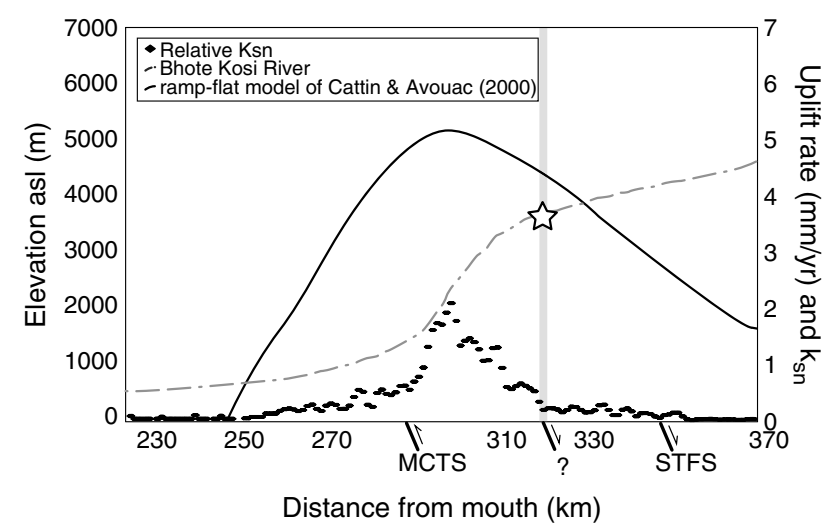

Figure 9. Comparison of channel steepness $\left(\mathrm{k}_{\mathrm{s}}\right)$ along the Bhote Kosi River with uplift pattern predicted by the ramp-flat model of Cattin and Avouac [2000]. The correlation between the fault proposed in the text and an increase in channel steepness is indicated. Inset map shows relative uplift from channel steepness (where uplift $\approx \mathrm{k}_{\mathrm{s}}^{2}$ ) and apparent exhumation rate from thermochronologic data (assuming exhumation rate scales linearly with cooling rate). 
not considered by Lavé and Avouac [2001] is required to fully explain the morphology of $\mathrm{PT}_{1}$. Moreover, and perhaps more importantly, the ramp-flat model does not predict any abrupt changes in cooling history in the vicinity of $\mathrm{PT}_{1}$.

[33] The third hypothesis invokes young faultingwhether related to the latest stages of STFS activity or a distinctive tectonic event-as the mechanism setting and maintaining $\mathrm{PT}_{1}$. A top-to-the-north normal fault or an oblique fault with a significant component of $\mathrm{N}$-directed normal slip, for example, would drive differential uplift in the footwall relative to the hanging wall. Although largescale strike-slip faults have been mapped at high structural levels across the NW Himalaya [e.g., Murphy and Copeland, 2005], in the Nyalam region, a purely strike-slip fault would be inconsistent with the abrupt and significant change in exhumation seen at $\mathrm{PT}_{1}$, as no differential exhumation would occur between the footwall and the hanging wall. Careful analysis of satellite imagery in the vicinity reveals no evidence for large scale strike-slip in the drainage patterns near the physiographic discontinuity. The thermochronologic data do not preclude some strike-slip component to faulting at $\mathrm{PT}_{1}$, but they require significant normal displacement. If such a fault accommodated displacement significant enough to drive higher rock uplift rates in the footwall for a sustained period of time, the prominent break associated with the transition would be established and this uplift discontinuity would result in a sharp topographic break coinciding with offset low-temperature thermochronologic cooling ages (AHe, AFT) and likely higher temperature chronometers (ZHe, ZFT) reflecting different exhumation histories across the fault, as well as differential erosion rates likely manifesting as a change in channel steepness (i.e., a knickpoint) on river longitudinal profiles. The cooling age pattern and differential thermal history indicated by the data presented here at $\mathrm{PT}_{1}$ are consistent with predominately top-to-the-north normal faulting, as suggested by Hodges et al. [2001], although the faulting is not along previously mapped strands of the STFS [e.g., Burchfiel et al., 1992]. Both of our independent data sets, geomorphically inferred erosion rates and all thermochronologic data except two young $\mathrm{AHe}$ above $\mathrm{PT}_{1}$, indicate sharp discontinuities at $\mathrm{PT}_{1}$. Although we recognize that complicating factors likely exist - for example, perturbations in the geothermal gradient related to changing uplift patterns through time - we make the first-order simplifying assumptions that channel steepness scales with uplift rate (where uplift $\approx \mathrm{k}_{\mathrm{s}}^{2}$; Ouimet et al. [2009]; DiBiase et al. [2010]) and that cooling rate scales linearly with exhumation rate. When the two data sets are compared with each other given these assumptions, they exhibit consistent patterns, strong evidence that, despite unknown complicating factors, both datasets may scale with exhumation rate. If this is true, then both datasets indicate a sharp and temporally persistent increase in exhumation rate at the location of $\mathrm{PT}_{1}$, data consistent with surface-breaking, top-to-the-north extensional faulting with significant relative exhumation of the footwall.

[34] Access to the area around $\mathrm{PT}_{1}$ in the Nyalam area is restricted by national and local authorities to the rightof-way of the Friendship Highway, which runs parallel to the Bhote Kosi gorge and high above river level. The landscape is steep and heavily vegetated; bedrock outcrops are few along this stretch of the highway, and most roadcuts are in landslides. Despite our best efforts at field mapping given these constraints, we were unable to find evidence for or against the existence of a surface-breaking fault at $\mathrm{PT}_{1}$. A better field evaluation of the possibility of a fault at this structural level will require better access to transverse river valleys that may contain pertinent bedrock exposures.

[35] We find that the preponderance of available data are consistent with the fault control model (featuring the initiation of extensional faulting at $\sim 3.5 \mathrm{Ma}$ ) and inconsistent with the margin retreat model. While the midcrustal ramp model cannot explain the abrupt change in cooling age patterns at $\mathrm{PT}_{1}$ given any reasonable geometry of the ramp or associated duplex system at depth, none of the data presented here are inconsistent with the existence of such structures at depth. In fact, the suggestion in the low-temperature thermochronometric data of a progressive increase in exhumation rate southward from $\mathrm{PT}_{1}$ in Plio-Pleistocene time is consistent with the growth of a midcrustal duplex below [e.g., Lavé and Avouac, 2001].

\section{Tectonic Significance}

[36] The simplest explanation, consistent with a preponderance of the data reviewed in this paper, is that the exhumation discontinuity at $\mathrm{PT}_{1}$ in the Nyalam transect is set and controlled by recently active extensional faulting, likely initiating at $\sim 3.5 \mathrm{Ma}$, occurring simultaneously with uplift over a midcrustal ramp or an actively growing Lesser Himalayan duplex. The Bhote Kosi channel south of $\mathrm{PT}_{1}$ displays higher steepness as river incision and erosion work to balance higher uplift rates downstream. The thermochronologic data suggest a sustained difference in exhumation history across the knickpoint since $\sim 3.5 \mathrm{Ma}$, with very young cooling ages, likely indicating high exhumation rates, to the south of the knickpoint. The coincidence of this prolonged differential cooling over several million years with the geomorphic break representing very recent deformation today lends significance to this specific location that is best explained by Plio-Pleistocene top-to-the-north normal faulting.

[37] The geomorphic and thermochronologic patterns discussed here are not unique to the Nyalam region. Across the central Himalaya $\left(\sim 83^{\circ} \mathrm{E}-86.5^{\circ} \mathrm{E}\right), \mathrm{PT}_{1}$ is well defined, exhibited by a distinct morphologic break associated with a zone of high channel steepness and fluvial incision, inferred to be a zone of high uplift (Figure 2). Although lowtemperature thermochronologic studies across the central Himalaya are not yet plentiful, to the south of $\mathrm{PT}_{1}$, lowtemperature thermochronologic cooling ages are young, generally Plio-Pleistocene [Arita and Ganzawa, 1997; Blythe et al., 2007; Streule et al., 2012; J. A. McDermott et al., in review], as compared to the north on the physiographic plateau, where cooling ages are Middle Miocene or older [Searle et al., 1997; Crouzet et al., 2007; Streule et al., 2012; $J$. A. McDermott et al., in review]. In most locations across the central Himalaya, the nature of the cooling age transition across $\mathrm{PT}_{1}$, e.g., abrupt or gradual, is not well constrained. One exception is the Kali Gandaki valley in central Nepal, where $J$. A. McDermott et al. (in review) document significant Pleistocene slip on a top-to-the-north extensional fault at the approximate location of $\mathrm{PT}_{1}$ that represents a distinct break in cooling ages, juxtaposing Pleistocene ages in the footwall against Late Miocene ages in the hanging wall. If our interpretation of the geomorphic and thermochronologic data at $\mathrm{PT}_{1}$ in 
Nyalam is correct, top-to-the-north normal faulting at $\mathrm{PT}_{1}$ may be a regional feature across the central Himalaya.

[38] If indeed a regional structure, faulting at $\mathrm{PT}_{1}$ could serve to accommodate the transition from E-W extension occurring across the Tibetan Plateau to N-directed convergence within the Himalayan realm, as first suggested by Hodges et al. [2001]. A compatible hypothesis [Murphy and Copeland, 2005] proposed that the Karakorum fault and possibly linked structures, such as the Gurla Mandhata-Humla fault system in the northwestern Himalaya, serve as transfer structures between the contrasting convergent and extensional regimes and migrate southward with time with the fold-thrust belt. Some evidence suggests that E-W extension, characteristic of the Tibetan domain, has propagated southward into the Himalaya since the Miocene [Meyer et al., 2006; Jessup et al., 2008; Hintersberger et al., 2010, 2011]. In the Nyalam region, $\mathrm{PT}_{1}$ lies $\sim 30 \mathrm{~km}$ to the south of the STFS (Figure 3 ), consistent with the model if faulting at $\mathrm{PT}_{1}$ currently sets the southern limit of E-W extension. This southward progression pattern, however, is not ubiquitous across the central Himalaya, and in some locations, such as the Kali Gandaki valley where $\mathrm{N}$-directed normal faulting at $\mathrm{PT}_{1}$ has been documented (J.A. McDermott et al., in review), young $\sim \mathrm{E}-\mathrm{W}$ striking faults lie near, but structurally higher than, the STFS. An alternate hypothesis put forth in the NW Himalaya describes the southward propagating E-W extensional front as diffuse, the result of accommodation of extension along numerous small structures rather than limited to one major structure [Hintersberger et al., 2010]. Unlike in the NW Himalaya, across the central Himalaya $\left(\sim 83^{\circ} \mathrm{E}-86.5^{\circ} \mathrm{E}\right)$, we know of no $\mathrm{N}-\mathrm{S}$ striking faults linked to plateau extension that transect $\mathrm{PT}_{1}$; in the Nyalam region, all known N-S striking normal faults lie $>20 \mathrm{~km}$ to the north of the transition (Figure 3), and in central Nepal, perhaps the best studied area of the central Himalaya, numerous N-S striking faults have been mapped cutting across the plateau and striking into the Himalaya, yet no structures are known to cut to the south of $\mathrm{PT}_{1}$. This suggests that $\mathrm{PT}_{1}$ may mark the position of a significant structure separating domains of $\mathrm{N}$-directed convergence within the Himalaya and E-W extension across the Tibetan Plateau [Hurtado et al., 2001; Hodges et al., 2001]. If this is true, and strike-slip faulting serves as a similar boundary in the NW Himalaya [Murphy and Copeland, 2005], a potential relationship between normal faulting at $\mathrm{PT}_{1}$ in the central Himalaya must exist. Murphy and Copeland [2005] suggest correlation of the strike-slip Gurla Mandhata-Humla fault system to a system of predominantly top-to-the-north normalsense faults with a right-lateral oblique slip component mapped across western Nepal (from west to east, the Darma, Talphi, Tibrikot, and Dhaulagiri Southwest faults of Nakata [1989]). These faults display clear evidence for Quaternary right-lateral oblique slip with large faceted scarps, offset fluvial and moraine deposits, and the formation of distinctive sag ponds in the hanging wall. The right-lateral component appears to decrease to the east as the western faults display consistent evidence for right-lateral offset while the Dhaulagiri Southwest fault appears to be predominantly top-to-the-north normal dip-slip [Nakata, 1989]. The system of faults has been linked to reactivated strands of the MCTS [Nakata, 1989], as well as possible projection to the Main Boundary thrust system [Nakata, 1989; Murphy and Copeland, 2005], but the eastern extent of the system remains uncertain. Located
$30 \mathrm{~km}$ to the west of the furthest mapped extent of the Dhaulagiri Southwest fault, the Dhaulagiri detachment is a Pleistocene top-to-the-north normal fault with minor rightlateral slip as inferred from shear sense indicators and crosscutting relationships (J.A. McDermott et al., in review). The similar Quaternary-age displacement and sense of shear of these two faults suggests they may be correlative, rather than the complicated structural configuration required for transition to the thrust-sense Main Boundary thrust system. If true, and if the Dhaulagiri detachment, a recently active top-to-thenorth normal fault at $\mathrm{PT}_{1}$ (J.A. McDermott et al., in review) is correlative to the Nyalam fault at $\mathrm{PT}_{1}$ as suggested here, then faulting at $\mathrm{PT}_{1}$ may represent the eastern continuation of strike-slip faulting that dominates the NW Himalaya, although with a dominant component of dip-slip in the central Himalaya. Regardless of such a potential connection, given the newly presented data from the Nyalam region, as well as documented recently active extension near $\mathrm{PT}_{1}$ in a location several hundred kilometers to the west (J.A. McDermott et al., in review) and the similar geomorphic and thermochronologic character across the central Himalaya, we infer that active normal faulting helps define the southern edge of the central Tibetan Plateau.

[39] Acknowledgments. The authors would like to thank Matthew Rossi for assistance in the field and Erchie Wong and Rinchin Goshampa and crew of Tibet Wind Horse Adventures for logistical support. This work was supported by the NSF Tectonics Program (EAR0711140).

\section{References}

Arita, K., and Y. Ganzawa (1997), Thrust tectonics and uplift process of the Nepal Himalaya revealed from fission-track ages, J. Geogr. Jpn., 106, 156-167.

Armijo, R., Tapponnier, P., Mercier, J. L., and T. L. Han (1986), Quaternary extension in southern Tibet: Field observations and tectonic implications, J. Geophys. Res., 91, 13,803-13,872.

Blisniuk, P. M., B. R. Hacker, J. Glodny, L. Ratschbacher, S. Bi, Z. Wu, M. O. McWilliams, and A. Calvert (2001), Normal faulting in central Tibet since at least 13.5 Mry ago, Lett. Nature, 412, 628-631.

Blythe, A. E., D. W. Burbank, A. Carter, K. Schmidt, and J. Putkonen (2007), Plio-Quaternary exhumation history of the central Nepalese Himalaya: 1. Apatite and zircon fission track and apatite [U-Th]/He analyses, Tectonics, 26, doi:10.1029/2006TC001990.

Bollinger, L., P. Henry, and J. P. Avouac (2006), Mountain building in the Nepal Himalaya; thermal and kinematic model, Earth Planet. Sci. Lett., 244, 58-71, doi:10.1016/j.eps1.2006.01.045.

Brandon, M. T., M. K. Roden-Tice, and J. I. Garver (1998), Late Cenozoic exhumation of the Cascadia accretionary wedge in the Olympic Mountains, northwest Washington State, Geol. Soc. Am. Bull., 110, 985-1009.

Brown, R. L., and J. H. Nazarchuk (1993), Annapurna detachment fault in the Greater Himalaya of central Nepal, in Himalayan Tectonics, edited by P. J. Treloar and M. P. Searle, Spec. Publ. Geol. Soc. London, 74, 461-473.

Burchfiel, B. C., C. Zhileng, K. V. Hodges, L. Yuping, L. H. Royden, D. Changrong, and X. Jiene (1992), The South Tibetan detachment system, Himalayan orogen: Extension contemporaneous with and parallel to shortening in a collisional mountain belt, Geol. Soc. Am. Spec. Pap., 269, 1-41.

Burg, J. P., M. Brunel, D. Gapais, G. M. Chen, and G. H. Liu (1984), Deformation of leucogranites of the crystalline Main Central Sheet in southern Tibet (China), J. Struct. Geol., 6, 535-542.

Catlos, E. J., T. M. Harrison, M. P. Searle, and M. S. Hubbard (1999), Evidence for late Miocene reactivation of the Main Central thrust: From Garhwal to the Nepali Himalaya (abs.), in Terra Nostra 99/2, 14th Himalaya-Karakoram-Tibet Workshop, March 1999, edited by E. Sobel et al., pp. 20-22, abstract volume, Selbstverlag der Alfred-WegenerStiftung, Kloster Ettal Germany, Cologne, Germany.

Cattin, R., and J. P. Avouac (2000), Modeling mountain building and the seismic cycle in the Himalaya of Nepal, J. Geophys. Res., 105, 13,389-13,407.

Colchen, M., P. LeFort, and A. Pecher (1986), Annapurna-ManasluGanesh Himal, 136 p., Cent. Natl. de la Rech. Sci., Paris.

Coleman, M. E. (1996), Orogen-parallel and orogen-perpendicular extension in the central Nepalese Himalayas, Geol. Soc. Am. Bull., 108, 1594-1607. 


\section{MCDERMOTT ET AL.: ACTIVE N-S EXTENSION AT HIMALAYAN CREST}

Coleman, M. E. (1998), U-Pb constraints on Oligocene-Miocene deformation and anatexis within the central Himalaya, Marsyandi valley, Nepal, Am. J. Sci., 298, 553-571.

Coleman, M. E., and K. V. Hodges (1995), Evidence for Tibetan plateau uplift before $14 \mathrm{~m} . \mathrm{y}$. ago from a new minimum age for east-west extension, Nature, 374, 49-52.

Crouzet, C., I. Dunkl, L. Paudel, P. Arkai, T. M. Rainer, K. Balogh, and E. Appel (2007), Temperature and age constraints on the metamorphism of the Tethyan Himalaya in central Nepal: A multidisciplinary approach, J. Asian Earth Sci., 30, 113-130, doi:10.1016/j.jseaes.2006.07.014.

Cyr, A. J., D. E. Granger, V. Olivetti, and P. Molin (2010), Quantifying rock uplift rates using channel steepness and cosmogenic nuclidedetermined erosion rates; examples from northern and southern Italy, Lithosphere, 2, 188-198, doi: 10.1130/L96.1.

Dahlen, F. A. (1990), Critical taper model of fold-and-thrust belts and accretionary wedges, Ann. Rev. Earth Planetary Sci., 18, 55-99.

DeCelles, P. G., G. E. Gehrels, J. Quade, T. P. Ojha, P. A. Kapp, and B. N. Upreti (1998a), Neogene foreland deposits, erosional unroofing, and the kinematic history of the Himalayan fold-thrust best, western Nepal, Geol. Soc. Am. Bull., 110, 2-21.

DeCelles, P. G., Gehrels, G. E., Quade, J., and T. P. Ojha (1998b), Eoceneearly Miocene foreland basin development and the history of Himalayan thrusting, western and central Nepal, Tectonics, 17, 741-765.

DeCelles, P. G., D. M. Robinson, J. Quade, T. P. Ojha, C. N. Garzione, P. Copeland, and B. N. Upreti (2001), Stratigraphy, structure and tectonic evolution of the Himalayan fold-thrust best in western Nepal, Tectonics, 20, 487-509.

DiBiase, R. A., K. X. Whipple, A. M. Heimsath, and W. B. Ouimet (2010), Landscape form and millennial erosion rates in the San Gabriel Mountains, CA, Earth Planet. Sci. Lett., 289, 134-144, doi:10.1016/j. eps1.2009.10.036.

Dougherty, A., M. Krol, and K. Hodges (1998), Miocene tectonic unroofing and cooling of the greater Himalayan sequence, Nyalam region, southern Tibet, Geol. Soc. Am. Abstr. Prog, 30(7), 270.

Edwards, M. A., and T. M. Harrison (1997), When did the roof collapse? Late Miocene north-south extension in the high Himalaya revealed by $\mathrm{Th}-\mathrm{Pb}$ monaizte dating of the Khula Kangri granite, Geology, 25, 543-546.

Evans, N. J., J. P. Byrne, J. T. Keegan, and L. E. Dotter (2005), Determination of uranium and thorium in zircon, apatite, and fluorite: Application to laser (U-Th)/He thermochronology, J. Anal. Chem., 60, 1159-1165, doi:10.1007/s10809-005-0260-1.

Farley, K. A., R. A. Wolf, and L. T. Silver (1996), The effects of long alphastopping distances on (U-Th)/He ages, Geochim. Cosmochim. Acta, 60, 4223-4229.

Farley, K. A. (2000), (U-Th)/He dating: Techniques, calibrations and applications, Rev. Min. Geochem., 47, 819-844.

Flowers, R. M., D. L. Shuster, B. P. Wernicke, and K. A. Farley (2007), Radiation damage control on apatite $(\mathrm{U}-\mathrm{Th}) / \mathrm{He}$ dates from the Grand Canyon region, Colorado Plateau, Geology, 35(5), 447-450.

Gansser, A. (1964), Geology of the Himalayas, 289 pp., Wiley Interscience, London.

Godard, V., and D. W. Burbank (2011), Mechanical analysis of controls on strain partitioning in the Himalayas of central Nepal, J. Geophys. Res., 116, doi:10.1029/2011JB008272.

Godin, L., R. L. Brown, and S. Hanmer (1999), High strain zone in the hanging wall of the Annapurna detachment, central Nepal Himalaya, in Himalaya and Tibet: Mountain Roots to Mountain Tops, edited by A. Macfarlane, R. B. Sorkhabi, and J. Quade, Geol. Soc. Am. Spec. Pap., Boulder, Colorado, 328, 199-210.

Harrison, T. M., I. Duncan, and I. McDougall (1985), Diffusion of ${ }^{40} \mathrm{Ar}$ in biotite: Temperature, pressure and compositional effects, Geochim. Cosmochim. Acta, 49, 2461-2468.

Harrison, T. M., K. D. McKeegan, and P. LeFort (1995), Detection of inherited monazite in the Manaslu leucogranite by ${ }^{208} \mathrm{~Pb} /{ }^{232} \mathrm{Th}$ ion microprobe dating: Crystallization age and tectonic significance, Earth Planet. Sci. Lett., 133, 271-282.

Harrison, T. M., F. J. Ryerson, P. Le Fort, A. Yin, O. Lovera, and E. J. Catlos (1997), A late Miocene-Pliocene origin for the central Himalayan inverted metamorphism, Earth Planet. Sci. Lett., 146, E1-E7.

Herman, F., et al. (2010), Exhumation, crustal deformation, and thermal structure of the Nepal Himalaya derived from the inversion of thermochronological and thermobarometric data and modeling of the topography, J. Geophys. Res., 115, doi:10.1029/2008JB006126.

Hintersberger, E., R. C. Thiede, M. R. Strecker, and B. R. Hacker (2010), East-west extension in the NW Indian Himalaya, Geol. Soc. Am. Bull., 122, 1499-1515, doi:10.1130/B26589.1.

Hintersberger, E., R. C. Thiede, and M. R. Strecker (2011), The role of extension during brittle deformation within the NW Indian Himalaya, Tectonics, 30, TC3012, doi:10.1029/2010TC002822.
Hodges, K. V. (2000), Tectonics of the Himalaya and southern Tibet from two perspectives, Geol. Soc. Am. Bull., 112, 324-350.

Hodges, K. V., J. M. Hurtado, and K. X. Whipple (2001), Southward extrusion of Tibetan crust and its effect on Himalayan tectonics, Tectonics, 20, 799-809.

Hodges, K. V., B. C. Burchfiel, L. H. Royden, Z. Chen, and Y. Liu (1992), The metamorphic signature of contemporaneous extension and shortening in the central Himalayan Orogen; data from the Nyalam transect, southern Tibet, J. Metamorph. Geol., 11, 721-737.

Hodges, K. V., B. C. Burchfiel, L. H. Royden, Z. Chen, and Y. Liu (1993), The metamorphic signature of contemporaneous extension and shortening in the central Himalayan Orogen; Data from the Nyalam transect, southern Tibet, J. Metamorph. Geol., 11, 721-737.

Hodges, K. V., R. R. Parrish, and M. P. Searle (1996), Tectonic evolution of the Central Annapurna Range, Nepalese Himalayas, Tectonics, 20(6), 1264-1291.

Hodges, K. V., C. Wobus, K. Ruhl, T. Schildgen, and K. Whipple (2004), Quaternary deformation, river steepening, and heavy precipitation at the front of the Higher Himalayan ranges, Earth Planet. Sci. Lett., 220, 379-389, doi:10.1016/S0012-821X(04)00063-9.

Hourigan, J. K., P. W. Reiners, and M. T. Brandon (2005), U-Th zonationdependent alpha-ejection in (U-Th)/He chronometry, Geochim. Cosmochim. Acta, 69, 3349-3365.

Hubbard, M. S., and T. M. Harrison (1989), ${ }^{40} \mathrm{Ar} /{ }^{39} \mathrm{Ar}$ age constraints on deformation and metamorphism in the Main Central thrust zone and Tibetan slab, eastern Nepal Himalaya, Tectonics, 8, 865-880.

Hurtado, J. M., K. V. Hodges, and K. X. Whipple (2001), Neotectonics of the Thakkhola Graben and implications for Recent activity on the South Tibetan Fault System in the central Nepalese Himalaya, Geol. Soc. Am. Bull, 113, 222-240.

Jessup, M. J., D. L. Newell, J. M. Cottle, A. L. Berger, and J. A. Spotila (2008), Orogen-parallel extension and exhumation enhanced by denudation in the trans-Himalayan Arun River gorge, Ama Drime Massif, Tibet-Nepal, Geology, 36, 587-590, doi:10.1130/G24722A.1.

Kirby, E., and K. X. Whipple (2012), Expression of active tectonics in erosional landscapes, J. Struct. Geol., 44, doi:10.1016/j.jsg.2012.07.009.

Lavé, J., and J. P. Avouac (2000), Active folding of fluvial terraces across the Siwaliks Hills, Himalayas of central Nepal, J. Geophys. Res., 105, 5735-5770.

Lavé, J., and J. P. Avouac (2001), Fluvial incision and tectonic uplift across the Himalayas of central Nepal, J. Geophys. Res., 106, 26,561-26,591.

Le Fort, P. (1975), Himalayas: The collided range. Present knowledge of the continental arc, Am. J. Sci., 275, 1-44.

Macfarlane, A., K. V. Hodges, and D. Lux (1992), A structural analysis of the Main Central thrust zone, Langtang National Park, central Nepal Himalaya, Geol. Soc. Am. Bull., 104, 1389-1402.

Maluski, H., P. Matte, and M. Brunel (1988), Argon-39-argon-40 dating of metamorphic and plutonic events in the North and High Himalaya belts (southern Tibet-China), Tectonics, 7, 299-326.

Masek, J. G., B. L. Isacks, T. L. Gubbels, and E. J. Fielding (1994), Erosion and tectonics at margins of continental plateaus, J. Geophys. Res., 99, 13941-13956.

Meade, B. J. (2010), The signature of an unbalanced earthquake cycle in Himalayan topography?, Geology, 38, 987-990, doi:10.1130/G31439.1.

Meigs, A., D. W. Burbank, and R. A. Beck (1995), Middle-late Miocene $(>10 \mathrm{Ma})$ initiation of the Main Boundary thrust in the western Himalaya, Geology, 23, 423-426.

Meyer, M. C., Wiesmayr, G., Brauner, M., Häusler, H., and D. Wangda (2006), Active tectonics in Eastern Lunana (NW Bhutan): Implications for the seismic and glacial hazard potential of the Bhutan Himalaya, Tectonics, 25, TC3001, doi:10.1029/2005TC001858.

Murphy, M. A., and P. Copeland (2005), Transtensional deformation in the central Himalaya and its role in accommodating growth of the Himalayan orogen, Tectonics, 24, TC4012, doi:10.1029/2004TC001659.

Myrow, P. M., N. C. Hughes, M. P. Searle, C. M. Fanning, S.-C. Peng, and S. K. Parcha (2009), Stratigraphic correlation of Cambrian-Ordovician deposits along the Himalaya: Implications for the age and nature of rocks in the Mount Everest region, Geol. Soc. Am. Bull, 121, 323-332, doi:10.1130/B26384.1.

Nakata, T. (1989), Active faults of the Himalaya of India and Nepal, in Tectonics of the Western Himalayas, Geol. Soc. Am. Spec. Publ., 232, edited by L. L. Malinconico and R. J. Lillie, Geol. Soc. Am. Spec. Publ, 232, 243-264.

Nazarchuk, J. H. (1993), Structure and geochronology of the Greater Himalaya, Kali Gandaki region, west-central Nepal, MSc thesis, Carleton Univ., Ottawa.

Ouimet, W. B., K. X. Whipple, and D. E. Granger (2009), Beyond threshold hillslopes; channel adjustment to base-level fall in tectonically active mountain ranges, Geology, 37, 579-582, doi:10.1130/G30013A.1.

Reiners, P. W. (2005), Zircon (U-Th)/He thermochronometry, Rev. Mineral. Geochem., 58, 151-179, doi:10.2138/rmg.2005.58.6. 


\section{MCDERMOTT ET AL.: ACTIVE N-S EXTENSION AT HIMALAYAN CREST}

Robert, X., P. van der Beek, J. Braun, C. Perry, M. Dubille, and J.-L. Mugnier (2009), Assessing Quaternary reactivation of the Main Central thrust zone (central Nepal Himalaya); New thermochronologic data and numerical modeling, Geology, 37, 731-734, doi:10.1130/ G25736A.1.

Schärer, U., R. Xu, and C. Allegre (1986), U-(Th)-Pb systematics and ages of Himalaya leucogranites, South Tibet, Earth Planet. Sci. Lett., 77, 35-48.

Schelling, D. (1992), The tectonostratigraphy and structure of the eastern Nepal Himalaya, Tectonics, 11, 925-943.

Searle, M. (1995), The rise and fall of Tibet, Nature, 374, 17-18.

Searle, M. P., and L. Godin (2003), The South Tibetan detachment and the Manaslu Leucogranite; a structural reinterpretation and restoration of the Annapurna-Manaslu Himalaya, Nepal, J. Geol., 111, 505-523.

Searle, M. P., R. R. Parrish, K. V. Hodges, A. Hurford, M. W. Ayres, and M. J. Whitehouse (1997), Shisha Pangma leucogranite, South Tibetan Himalaya: Field relations, geochemistry, age, origin, and emplacement, J. Geol., 105, 295-317.

Searle, M. P., S. R. Noble, A. J. Hurford, and D. C. Rex (1999), Age of crustal melting, emplacement and exhumation history of the Shivling leucogranite, Garhwal Himalaya, Geol. Mag., 136, 513-525.

Seeber, L., and V. Gornitz (1983), River profiles along the Himalayan arc as indicators of active tectonics, Tectonophysics, 92, 335-367.

Srivastava, P., and G. Mitra (1994), Thrust geometries and deep structure of the outer and Lesser Himalaya, Kumaon and Garhwal (India): Implications for evolution of the Himalayan fold-and-thrust belt, Tectonics, 13, 89-109.

Streule, M. J., A. Carter, M. P. Searle, and J. M. Cottle (2012), Constraints on brittle field exhumation of the Everest-Makalu section of the Greater Himalayan Sequence: Implications for models of crustal flow, Tectonics, 31, TC3010, doi: 10.1029/2011TC003062.

Vannay, J. C., and K. V. Hodges (1996), Tectonometamorphic evolution of the Himalayan metamorphic core between the Annapurna and Dhaulagiri, central Nepal, J. Metamorph. Geol., 14, 635-656.

van Soest, M. C., B. D. Monteleone, K. V. Hodges, and J. W. Boyce (2011), Laser depth profiling studies of helium diffusion in Durange fluorapatite, Geochim. Cosmochim. Acta, 75, 2409-2419, doi:10.1016/j.gca.2011.02.008.

Vermeesch, P., D. Seward, C. Latkoczy, M. Wipf, D. Günther, and H. Baur (2007), $\alpha$-Emitting mineral inclusions in apatite, their effect on (U-Th)/He ages, and how to reduce it, Geochim. Cosmochim. Acta, 71, 1737-1746, doi:10.1016/j.gca.2006.09.020.
Wager, L. R. (1937), The Arun River drainage pattern and the rise of the Himalaya, Geogr. J., 89, 12-41.

Wang, Y., J. Wang, and S. Wang (1998), Fission track evidence for rapid uplift of the Nyalam, Higher Himalaya, Tibet, China [in Chinese], Geol. Rev., 44, 430-434.

Wang, Y., Q. Li, G. Qu, R. D. Law, M. P. Searle, and L. Godin (2006), 40Ar/39Ar thermochronological constraints on the cooling and exhumation history of the South Tibetan detachment system, Nyalam area, southern Tibet, Geol. Soc. Am. Spec. Publ., 268, 327-354, doi:10.1144/GSL.SP.2006.268.01.16.

Wang, A., J. I. Garver, G. Wang, J. A. Smith, and K. Zhang (2010), Episodic exhumation of the Greater Himalayan Sequence since the Miocene constrained by fission track thermochronology in Nyalam, central Himalaya, Tectonophysics, 495, 315-323, doi:10.1016/j. tecto.2010.09.037.

Whipp, D. M., and T. A. Ehlers (2007), Influence of groundwater flow on thermochronometer--derived exhumation rates in the central Nepalese Himalaya, Geology, 35, 851-854, doi:10.1130/G23788A.1.

Wobus, C. W., K. V. Hodges, and K. X. Whipple (2003), Has focused denudation sustained active thrusting at the Himalayan topographic front?, Geology, 31, 861-864.

Wobus, C., A. Heimsath, K. Whipple, and K. Hodges (2005), Active out-of-sequence thrust faulting in the central Nepalese Himalaya, Nature, 434, 1008-1011, doi:10.1038/nature03499.

Wobus, C., K. X. Whipple, E. Kirby, N. Snyder, J. Johnson, K. Spyropolou, B. Crosby, and D. Sheehan (2006a), Tectonics from topography: Procedures, promise, and pitfalls, Geol. Soc. Am. Spec. Pap., 398, 55-74, doi:10.1130/2006.2398(04).

Wobus, C. W., K. X. Whipple, and K. V. Hodges (2006b), Neotectonics of the central Nepalese Himalaya: Constraints from geomorphology, detrital ${ }^{40} \mathrm{Ar} /{ }^{39} \mathrm{Ar}$ thermochronology, and thermal modeling, Tectonics, 25, TC4011, doi:10.1029/2005TC001935.

Wu, C., K. Nelson, G. Wortman, S. Samson, Y. Yue, J. Li, W. Kidd, and M. Edwards (1998), Yadong cross structure and South Tibetan detachment in the east central Himalaya $\left(89-90^{\circ} \mathrm{E}\right)$, Tectonics, 17, 28-45.

Yeats, R. S., T. Nakata, A. Farah, M. Fort, M. A. Mirza, M. R. Pandey, and R. S. Stein (1992), The Himalayan frontal fault system, Ann. Tectonicae, 6, 85-98. Zentmyer, R., P. M. Myrow, and D. L. Newell (2008), Travertine deposits from along the South Tibetan Fault System near Nyalam, Tibet, Geol. Mag., 145, 753-765. 